\title{
34. ORGANIC PETROGRAPHY AND EXTRACTABLE HYDROCARBONS OF SEDIMENTS FROM THE EASTERN NORTH PACIFIC OCEAN, DEEP SEA DRILLING PROJECT LEG 631
}

\author{
Jürgen Rullkötter, Institut für Erdöl und Organische Geochemie, Kernforschungsanlage Jülich GmbH, \\ D-5170 Jülich, Federal Republic of Germany \\ Hans von der Dick, Lehrstuhl für Geologie, Geochemie und Lagerstätten des Erdöls und der Kohle, \\ Rheinisch-Westfälische Technische Hochschule, D-5100 Aachen, Federal Republic of Germany \\ and \\ Dietrich H. Welte, Institut für Erdöl und Organische Geochemie, Kernforschungsanlage Jülich GmbH, \\ D-5170 Jülich, Federal Republic of Germany
}

\begin{abstract}
Quantity, type, and maturity of the organic matter of middle Miocene to Quaternary sediments from the eastern North Pacific (Deep Sea Drilling Project Leg 63) were determined. Hydrocarbons and fatty acids in lipid extracts were analyzed by capillary column gas chromatography and combined gas chromatography/mass spectrometry. Kerogens were investigated by Rock-Eval pyrolysis and microscopy, and vitrinite reflectance values were determined.

At Site 467, in the San Miguel Gap of the outer California Continental Borderland, organic carbon contents range from $1.46 \%$ to $5.40 \%$. Normalized to organic carbon, total extracts increase from about 10 to $36 \mathrm{mg} / \mathrm{g} \mathrm{C}_{\text {org }}$ with depth. The organic matter is a mixture of both marine and terrestrial origin, with the marine organic matter representing a high proportion in some of the samples. Steroid hydrocarbons-sterenes and steradienes in the upper part of the section and steranes in the deepest sample-are the most abundant compounds in the nonaromatic hydrocarbon fractions. Perylene, alkylated thiophenes, and aromatic steroid hydrocarbons dominate in the aromatic hydrocarbon fractions of the shallower samples; increasing maturation is indicated by a more petroleumlike aromatic hydrocarbon distribution. Microscopy revealed a high amount of liptinitic organic matter and confirmed the maturation trend as observed from analysis of the extracts. The vitrinite reflectance may be extrapolated to a bottom-hole value of nearly $0.5 \% \overline{\mathrm{R}_{\mathrm{o}}}$. The liquid hydrocarbon potential of the sediments at higher maturity levels is rated to be good to excellent.

At Site 471 , off Baja California, organic carbon values are between $0.70 \%$ and $1.12 \%$. Extract values increase with depth, as at Site 467. The investigation of the soluble and insoluble organic matter, despite some compositional similarities, consistently revealed a more terrigenous influx compared with Site 467 . Thus the potential for liquid hydrocarbon generation is lower, the organic matter being more gas-prone. The deepest sample analyzed indicates the onset of hydrocarbon generation. At this site, frequent sand intercalations offer pathways for migration and possibly reservoir formation.
\end{abstract}

\section{INTRODUCTION}

During DSDP Leg 63, thick sedimentary sequences were penetrated at Sites 467 and 471 in the eastern North Pacific Ocean off the coast of North America (Fig. 1). Hole 467 was drilled at the San Miguel Gap in the outer California Continental Borderland at a water depth of 2146 meters. Hole 471 (water depth 3115 meters) was drilled on the Pacific plate in a sedimentary wedge west of the foot of the continental slope off Baja California. At both sites the age of the sediment column ranges from middle Miocene to the present. The major objectives of DSDP Leg 63 were to determine the Neogene history of the California Current and the paleoecologic and paleoclimatic history of the northeastern Pacific.

Our study is concerned with the investigation of both the soluble and the insoluble organic matter in the sediments recovered from Holes 467 and 471. Compositional variations may reflect paleoenvironmental changes during sedimentation of organic matter as well as contribution from different sources. Furthermore,

\footnotetext{
${ }^{1}$ Initial Reports of the Deep Sea Drilling Project, Volume 63.
}

we are interested in the thermal maturation of the organic matter and in potential hydrocarbon source rocks in this area of high heat flow.

\section{SAMPLES}

Six samples each from Holes 467 and 471 were investigated. Tables 1 and 2 present information on depth, stratigraphy, and lithology of these samples.

\section{EXPERIMENTAL PROCEDURES}

The frozen samples were dried at $50^{\circ} \mathrm{C}$ for 12 hours and ground. Total carbon and organic carbon (after treatment with hydrochloric acid) were determined with a LECO carbon analyzer. Extraction was performed using a flow-blending technique (Radke et al., 1978) and dichloromethane as solvent. The total extracts were separated into nonaromatic hydrocarbons, aromatic hydrocarbons, and heterocomponents by automated medium-pressure liquid chromatography (Radke et al., 1980). Only samples selected for fatty-acid analysis were treated differently. In these cases, the total extracts were saponified by boiling in methanol/ $\mathrm{KOH}(5 \%)$ under reflux for 8 hours. The resultant mixtures were chromatographed on silica gel with methanol as eluant. The hydrocarbon fractions were separated from these eluates by medium-pressure liquid chromatography as above. The fatty acids were eluated from the silica gel column with methanolic hydrochloric acid and esterified with $\mathrm{BF}_{3} /$ methanol.

A Siemens L 402 gas chromatograph (GC) equipped with a $25-\mathrm{m}$ $\times 0.3-\mathrm{mm}$ (i.d.) glass capillary column coated with SE 54 was used for gas chromatographic analysis of the nonaromatic hydrocarbon frac- 


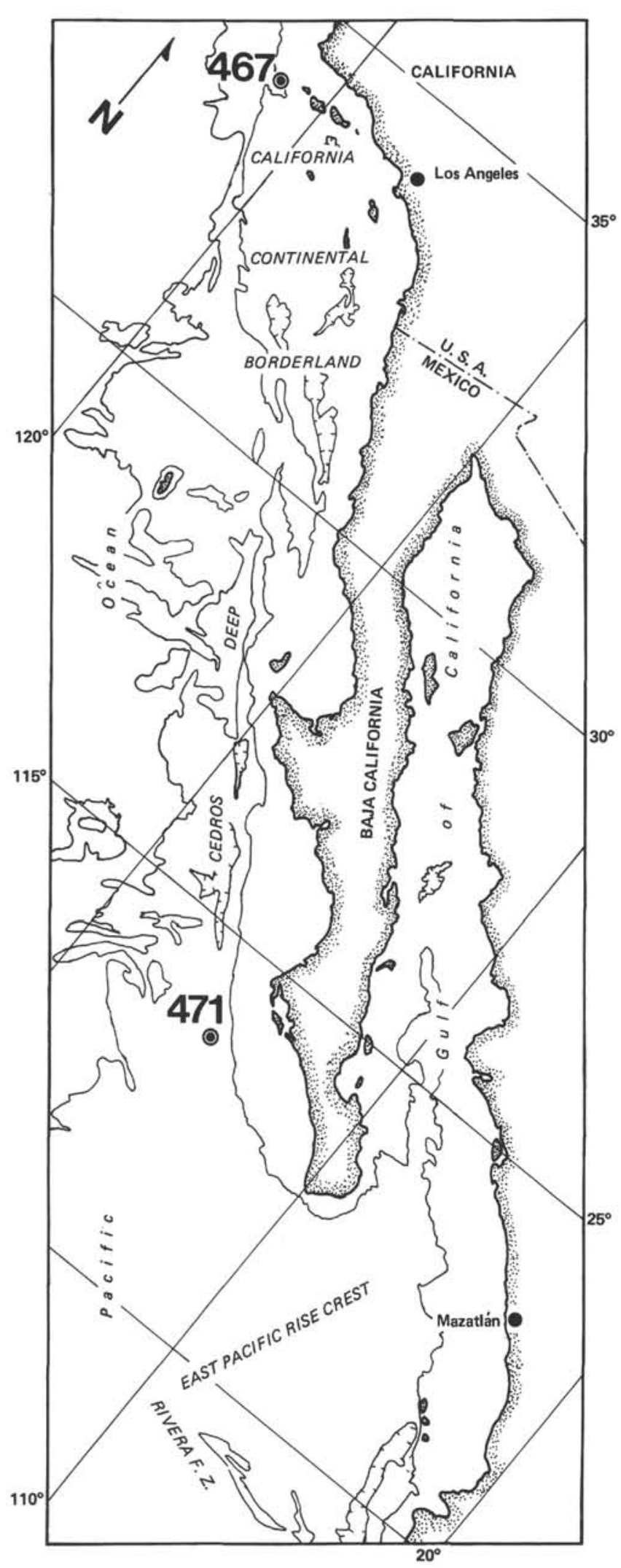

Figure 1. Location of DSDP Sites 467 and 471 in the eastern North Pacific Ocean. tions. Hydrogen was used as carrier gas. The temperature of the GC oven was programmed as follows: (1) $80^{\circ} \mathrm{C}$ for $2 \mathrm{~min}$, (2) $80^{\circ} \mathrm{C}$ to $250^{\circ} \mathrm{C}$ at a rate of $3^{\circ} \mathrm{C} / \mathrm{min}$, (3) $250^{\circ} \mathrm{C}(25 \mathrm{~min})$. Quantitative determination of alkane concentrations was performed relative to an external standard.

Gas chromatography/mass spectrometry (GC/MS) was carried out on a MS 3074 mass spectrometer (Kratos AEI) linked directly to a Pye 104 gas chromatograph via an open-split coupling. Samples were injected splitless onto a $25-\mathrm{m} \times 0.3$-mm i.d. glass capillary column coated with SE 54. Helium was used as a carrier gas, and the temperature was programmed from $100^{\circ} \mathrm{C}$ to $250^{\circ} \mathrm{C}$ at a rate of $4^{\circ} \mathrm{C} / \mathrm{min}$. The mass spectrometer was operated at an ionization energy of $70 \mathrm{eV}$. The source temperature was kept at $200^{\circ} \mathrm{C}$, and the magnet scanned continuously at a rate of $3 \mathrm{~s} / \mathrm{scan}$. All data were stored and processed using a DS 50S on-line data system (Kratos-AEI).

Rock-Eval (Rock-Evaluator) pyrolysis was performed according to the method first described by Espitalié et al. (1977). Hydrogen and oxygen contents of the rock samples were normalized to organic carbon and displayed as index values in a diagram adopted from Espitalié et al. (1977).

Kerogen concentrates for microscopic investigations were obtained from the ground samples by partial demineralization. Hydrochloric acid was used to remove carbonates, and a subsequent threefold treatment with concentrated aqueous $\mathrm{HCl} / \mathrm{HF}(30: 70 \%$ by volume) removed most of the silicates. $\mathrm{HCl} / \mathrm{HF}$ treatments were carried out in an autoclave at $40^{\circ} \mathrm{C}$. The residues were bloated in a $\mathrm{KI} / \mathrm{CdI}$ solution (density $1.95 \mathrm{~g} / \mathrm{cm}^{3}$ ) by ultrasonication, centrifuged, and the floating fractions trapped, washed, freeze-dried, and embedded in synthetic resin. After grinding and polishing, the kerogen concentrates were examined using a Zeiss Standard Universal reflected light microscope equipped with a $100 \times$ oil-immersion objective and a $40 \times$ air objective. During measurements, kerogen background matter consisting of a more or less intimate mixture of clay minerals, pyrite, amorphous organic matter, and rounded to angular particles less than $3 \mu \mathrm{m}$ in diameter was distinguished from angular, partly structured particles larger than $3 \mu \mathrm{m}$ in diameter. These particles larger than $3 \mu \mathrm{m}$ were used for measurement of maceral type distributions. Vitrinite reflectance (at $546 \mathrm{~nm}$ in oil) and reflectance histograms are based on particles larger than $10 \mu \mathrm{m}$ exhibiting a clear and dense shape against the granular matrix.

Although neither a total destruction of minerals nor a complete recovery of organic matter is possible by the fractionation steps, the organic matter visible under the microscope should reflect the general type and composition of the total organic matter incorporated in the sediments.

\section{RESULTS}

\section{Site 467, San Miguel Gap}

\section{Carbon Contents and Extractable Organic Matter}

The organic carbon contents are high in the upper part of the sedimentary column of Hole 467, i.e., in Lithologic Unit 1 and the upper part of Lithologic Unit 2. The measured values range between $3.70 \%$ and $5.40 \%$ organic carbon (Table 1). The organic carbon contents are slightly lower $(1.46-2.30 \%)$ in the core samples from the lower part of Lithologic Unit 2 and from Lithologic Unit 4 (Table 1). The inorganic (carbonate) carbon contents, which were determined as the difference between total carbon and organic carbon, are highest in Lithologic Unit $1(3.80 \%$ and $3.20 \%)$ and decrease in Lithologic Units 2 and 4. An exceptionally low value was obtained for Sample 467-63-2, 130-133 $(0.49 \%$; Table 1$)$. There is no general downhole trend or a clear relationship between organic and inorganic carbon contents. 
Table 1. Organic- and carbonate-carbon values and extract data for Hole 467 samples.

\begin{tabular}{|c|c|c|c|c|c|c|c|c|c|c|c|}
\hline \multirow[b]{2}{*}{$\begin{array}{c}\text { Sample } \\
\text { (interval in cm) }\end{array}$} & \multirow[b]{2}{*}{$\begin{array}{c}\text { Depth } \\
\text { (m) }\end{array}$} & \multirow[b]{2}{*}{ Age } & \multirow[b]{2}{*}{$\begin{array}{c}\text { Lithologic } \\
\text { Unit }\end{array}$} & \multirow[b]{2}{*}{ Lithology } & \multirow[b]{2}{*}{$\begin{array}{l}C_{\text {org }} \\
(\%)\end{array}$} & \multirow[b]{2}{*}{$\begin{array}{c}\mathrm{C}_{\text {carb }} \\
(\%)\end{array}$} & \multicolumn{2}{|c|}{ Extract } & \multicolumn{3}{|c|}{ Chromatographic Fractions (\%) } \\
\hline & & & & & & & ppm & $\begin{array}{l}\mathrm{mg} / \mathrm{g} \\
\mathrm{C}_{\text {org }}\end{array}$ & $\begin{array}{l}\text { Nonaromatic } \\
\text { Hydrocarbons }\end{array}$ & $\begin{array}{c}\text { Aromatic } \\
\text { Hydrocarbons }\end{array}$ & $\begin{array}{c}\text { Hetero- } \\
\text { compounds }\end{array}$ \\
\hline $467-13-4,132-148$ & 116.4 & late Pliocene & 1 & Calcareous claystone & 3.70 & 3.80 & 435 & 12 & 5.4 & 6.3 & 88.3 \\
\hline $467-36-2,133-150$ & 331.9 & early Pliocene & 1 & Silty nannofossil clay & 5.40 & 3.20 & 587 & 11 & 5.5 & 6.0 & 88.5 \\
\hline $467-54-2,100-115$ & 502.6 & late Miocene & 2 & Silty claystone & 4.37 & $2.70^{\mathrm{a}}$ & 543 & 12 & 6.2 & 7.4 & 86.4 \\
\hline $467-63-2,130-133$ & 588.3 & late Miocene & 2 & Calcareous claystone & 1.46 & $0.49^{\mathrm{a}}$ & 131 & 9 & 13.6 & 11.4 & 76.0 \\
\hline $467-97-2,105-109$ & 911.1 & middle Miocene & 4 & Calcareous claystone & 1.63 & 2.54 & 508 & 31 & 8.2 & 7.1 & 84.7 \\
\hline $467-104-1,145-150$ & 976.5 & middle Miocene & 4 & Silty claystone & 2.30 & $2.04^{\mathrm{a}}$ & 833 & 36 & 6.1 & 5.2 & 88.7 \\
\hline
\end{tabular}

a The carbonate content in some cases is not consistent with the general lithology taken from the shipboard core descriptions.

Table 2. Organic- and carbonate-carbon values and extract data for Hole 471 samples.

\begin{tabular}{|c|c|c|c|c|c|c|c|c|c|c|c|}
\hline \multirow[b]{2}{*}{$\begin{array}{c}\text { Sample } \\
\text { (interval in cm) }\end{array}$} & \multirow[b]{2}{*}{$\begin{array}{l}\text { Depth } \\
\text { (m) }\end{array}$} & \multirow[b]{2}{*}{ Age } & \multirow[b]{2}{*}{$\begin{array}{c}\text { Lithologic } \\
\text { Unit }\end{array}$} & \multirow[b]{2}{*}{ Lithology } & \multirow[b]{2}{*}{$\begin{array}{l}C_{\text {org }} \\
(\%)\end{array}$} & \multirow[b]{2}{*}{$\begin{array}{c}\mathrm{C}_{\text {carb }} \\
(\%)\end{array}$} & \multicolumn{2}{|c|}{ Extract } & \multicolumn{3}{|c|}{ Chromatographic Fractions (\%) } \\
\hline & & & & & & & ppm & $\begin{array}{l}\mathrm{mg} / \mathrm{g} \\
\mathrm{C}_{\text {org }}\end{array}$ & $\begin{array}{l}\text { Nonaromatic } \\
\text { Hydrocarbons }\end{array}$ & $\begin{array}{c}\text { Aromatic } \\
\text { Hydrocarbons }\end{array}$ & $\begin{array}{l}\text { Hetero- } \\
\text { compounds }\end{array}$ \\
\hline $471-3-2,120-137$ & 21.8 & Pleistocene & 1 & Silty nannofossil clay & 0.86 & 0.57 & 59 & 7 & 23.1 & 3.8 & 73.1 \\
\hline $471-13-7,112-130$ & 124.2 & late Miocene & 2 & Diatomaceous clay & 0.72 & 0.12 & 50 & 7 & 7.4 & 7.4 & 85.2 \\
\hline $471-34-2,103-107$ & 316.0 & late(?) Miocene & 4 & Silty claystone & 0.81 & 0.15 & 88 & 11 & 12.6 & 11.7 & 75.7 \\
\hline $471-44-1,100-118$ & 409.6 & middle Miocene & 4 & Silty claystone & 1.12 & 0.29 & 188 & 17 & 19.4 & 12.8 & 67.8 \\
\hline $471-57-3,100-126$ & 536.1 & middle Miocene & 4 & Silty claystone & 0.78 & 0.19 & 202 & 26 & 7.2 & 5.1 & 87.7 \\
\hline $471-69-3,135-150$ & 650.4 & middle Miocene(?) & 4 & Silty claystone & 0.70 & 0.07 & 257 & 37 & 8.3 & 4.8 & 86.9 \\
\hline
\end{tabular}

The amount of extractable organic matter (normalized to organic carbon) remains fairly constant in Lithologic Units 1 and 2, but shows a distinct increase in Lithologic Unit 4 (Fig. 2). The extract values in the upper part of the sedimentary column are around $10 \mathrm{mg} / \mathrm{g}$ $\mathrm{C}_{\text {org }}$, whereas $36 \mathrm{mg} / \mathrm{g} \mathrm{C}_{\text {org }}$ were obtained from the deepest sample in this hole (Table 1). In contrast to this depth trend, the liquid chromatographic separation of the total extracts revealed that the ratio of hydrocarbons to heterocomponents remains more or less constant throughout all samples (Table 1). Because of the low absolute amounts of hydrocarbons recovered, however, the accuracy of the fraction weights may be low.

\section{Rock-Eval Pyrolysis}

The results of the Rock-Eval pyrolysis classifies the organic matter in five of the sediment samples from Hole 467 as type II kerogens with some contribution of terrigenous organic matter (Fig. 3). Comparable pyrolysis results were obtained by Roucaché et al. (1979) on a number of Cretaceous deep-sea sediments from the Atlantic ocean, and our classification is in agreement with their system. The only exception in the Hole 467 series is the core sample from Section 467-63-2, which yielded a low hydrogen index and a very high oxygen in$\operatorname{dex}\left(217 \mathrm{mg} \mathrm{CO} 2 / \mathrm{g} \mathrm{C}_{\text {org }}\right.$ ). Sample 467-13-4, 132-148 cm also shows a fairly high oxygen index (Fig. 3), but this high oxygen index is consistent with the shallow burial of this sample $(116.4 \mathrm{~m})$.

\section{Nonaromatic Hydrocarbons}

The $n$-alkane and isoprenoid hydrocarbon distributions are similar within each lithologic unit but show some differences between different lithologic units (Fig. 4). The Pliocene samples (Lithologic Unit 1) from Sections 467-13-4 and 467-36-2 contain a dominance of long-chain $n$-alkanes with a maximum at $\mathrm{n}-\mathrm{C}_{29}$ and a pronounced odd/even-carbon-number predominance. The concentration of $n$-alkanes below $n-\mathrm{C}_{25}$ is low, as is the concentration of isoprenoid hydrocarbons. Phytane and pristane are about equal in concentration, with a slight predominance of phytane. Sections 467-54-2 and 467-63-2 (upper Miocene; Lithologic Unit 2) exhibit $n$-alkane distributions similar to those obtained for Unit 1. They contain much higher amounts of pristane and phytane, however, with phytane clearly dominating (Fig. 4). The highest absolute amount of $n$-alkanes in the Hole 467 series was found in Sample 467-63-2, $130-133 \mathrm{~cm}$.

The $n$-alkane distributions of the middle Miocene samples (Lithologic Unit 4) are much smoother compared to the other samples described above; the longchain $n$-alkanes are no longer predominant. Pristane and phytane show a similar abundance relative to the $n$-alkanes, as in the Lithologic Unit 2 samples. The pristane/phytane ratio, however, is above unity in the deepest two samples (Fig. 4).

A detailed investigation of the branched and cyclic hydrocarbons in the nonaromatic hydrocarbon fractions was performed by combined gas chromatography/ mass spectrometry. Figure 5 displays the capillary column gas chromatograms of the nonaromatic hydrocarbon fractions of two representative samples from Hole 467. Branched and cyclic hydrocarbons identified by interpretation of mass spectra and relative retention times are marked and listed in Table 3 together with estimated relative abundances for all Hole 467 samples.

The samples from Lithologic Units 1 (Pliocene) and 2 (upper Miocene) are characterized by a dominance of numerous unsaturated hydrocarbons. Two isomeric pristenes and three phytenes were detected in Sections 46736-2 (Fig. 5), 467-54-2, and 467-63-2 with increasing relative abundances (Table 3 ). Lack of reference material did not allow assignment of double-bond locations. 


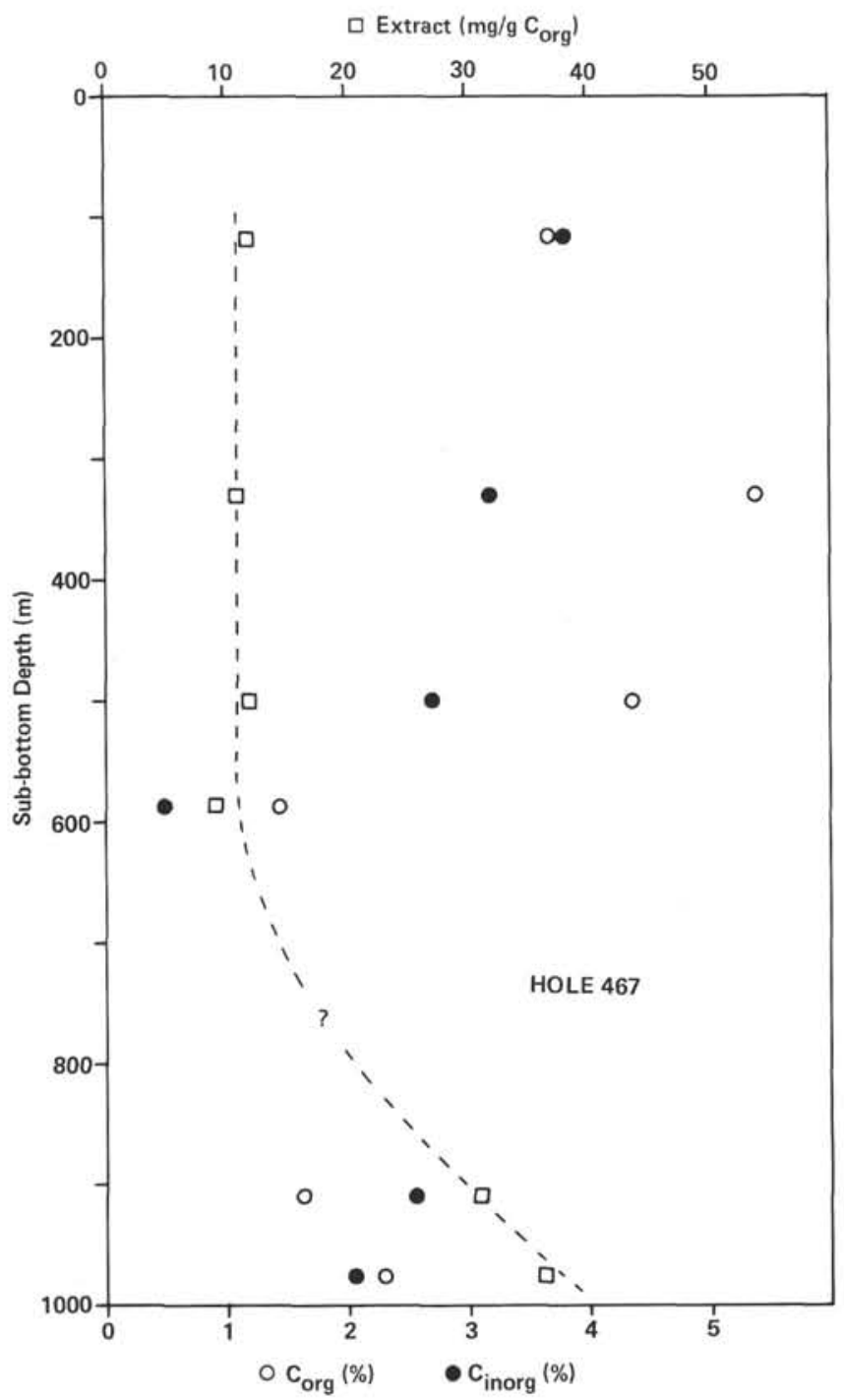

Figure 2. Organic and inorganic carbon contents and the trend of increasing extractable organic matter with depth for DSDP Hole 467 samples.

Regular sterenes and steradienes are the most abundant unsaturated cyclic hydrocarbons in the uppermost four samples, whereas only minor amounts of rearranged sterenes (I) are present (see the Appendix for structural formulas). Regular sterenes appear as ster-4-enes (II) and ster-5-enes (III), and the isomeric pairs are of nearly equal abundance. Cholestenes $\left(\mathrm{C}_{27}\right)$ are generally slightly more abundant than 2-ethylcholestenes $\left(\mathrm{C}_{29}\right)$; the concentration of 24-methylcholestenes $\left(\mathrm{C}_{28}\right)$ is considerably lower. An exception is found in Section 467-54-2, where all three homologs are major constituents. Steradienes (IV) also appear as $\Delta^{4}$ - and $\Delta^{5}$-isomers, with the second double bond at the $\mathrm{C}-22$ position in the side-chain, which has been deduced from the mass-spectrometric fragmentation pattern (cf. Wyllie and Djerassi, 1968). The 24-methylcholestadienes $\left(\mathrm{C}_{28}\right)$ are the most abundant homologs in this series. Saturated steranes (V) represent only a minor portion of the nonaromatic hydrocarbons in samples from Lithologic Units 1 and 2. The

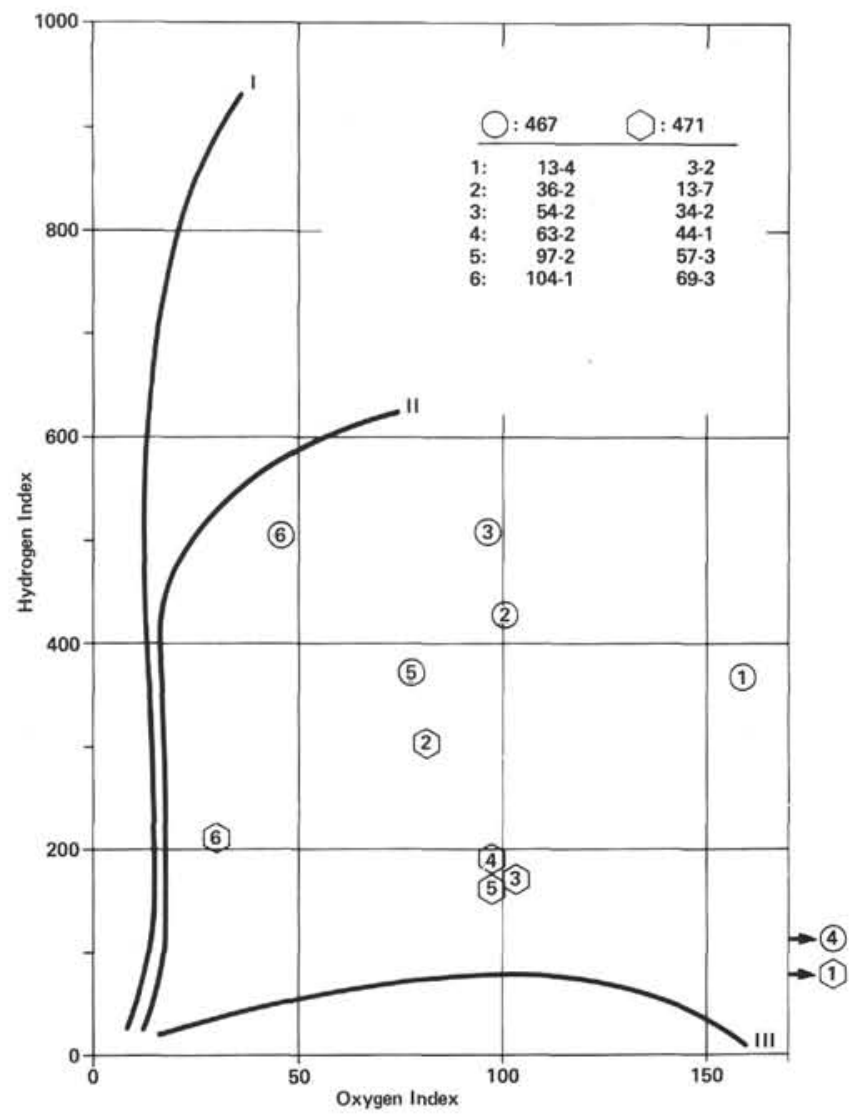

Figure 3. Results of Rock-Eval pyrolysis displayed as a hydrogen index versus oxygen index diagram (Espitalié et al., 1977) for samples from DSDP Holes 467 and 471.

$\mathrm{C}_{27}$ to $\mathrm{C}_{29}$ homologs are present in all four samples. A $\mathrm{C}_{26}$-sterane (VI ?), probably derived from well-known marine $C_{26}$-sterols (Djerassi et al., 1979), was only detected in Section 467-36-2 (Fig. 5); 4-methylsteranes (VIII) are trace constituents in all four samples.

Among the triterpene hydrocarbons, hop-17(21)-ene (IX) and hop-13(18)-ene-II (X) are the most abundant representatives in the four core samples from Lithologic Units 1 and 2. The structures of other $C_{30}$-triterpenes (Table 3 ) could not be elucidated unambiguously. A $\mathrm{C}_{28}$-triterpane, $17 \alpha(\mathrm{H}), 18 \alpha(\mathrm{H}), 21 \beta(\mathrm{H})-28,30$-bisnorhopane (XI), is present in all four samples and is the most abundant constituent in Section 467-36-2 (Fig. 5). This compound has been identified in the nearby Monterey shale (Miocene) by Seifert et al. (1978). Because of the extremely high concentrations in this shale, small amounts of eroded and redeposited sediment material may account for the presence of the $\mathrm{C}_{28}$-triterpane in the Hole 467 samples. The same compound was also detected in particulate matter trapped from seawater in the nearby Santa Barbara Basin (Crisp et al., 1979). Regular hopanes identified are both from the $17 \alpha(\mathrm{H})$-(XII) and $17 \beta(\mathrm{H})$-series (XIII). They are mostly minor or trace constituents (Table 3 ); the highest concentrations were found for $17 \alpha(\mathrm{H})$-hopane and $17 \beta(\mathrm{H})$-homohopane. No moretanes with $17 \beta(\mathrm{H}), 21 \alpha(\mathrm{H})$-stereochemistry (XIV) were detected. 


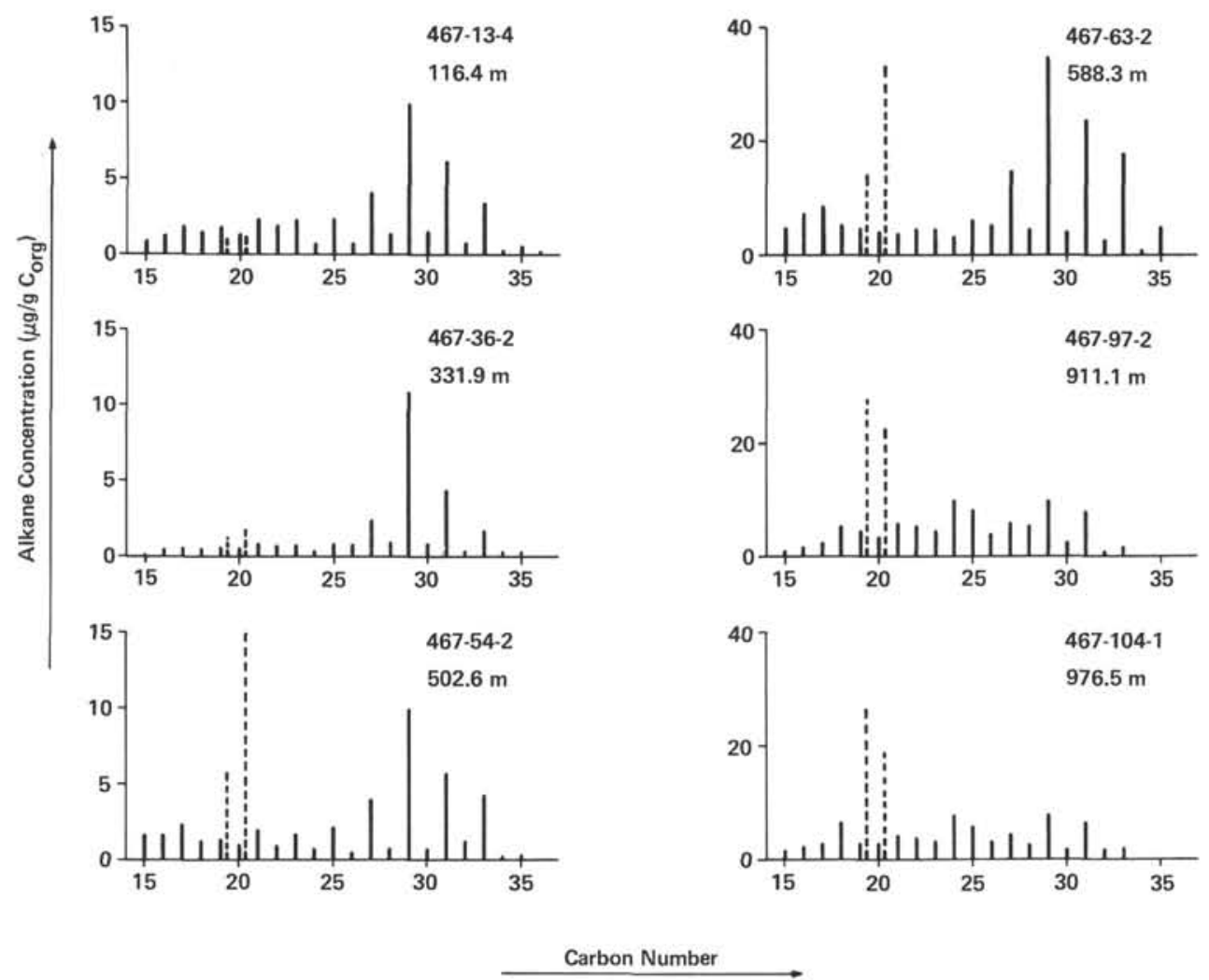

Figure 4. $\mathrm{N}$-alkane (solid lines) and isoprenoid hydrocarbon (dotted lines) distributions (absolute concentrations) for samples from DSDP Hole 467. (Note different vertical scales on left-and right-hand sides of the figure.)

The nonaromatic hydrocarbon fractions of the samples from Lithologic Unit 4 (middle Miocene) exhibit a clearly different composition. Regular unsaturated steroid hydrocarbons are minor constituents in Section 467-97-2 $(911.1 \mathrm{~m})$ and have completely disappeared in Section 467-104-1 $(976.5 \mathrm{~m})$, as shown in Table 3. In contrast, the relative amount of rearranged sterenes (I) has slightly increased compared to the shallower samples. Saturated steranes (V) with both $5 \beta$ - and $5 \alpha$ stereochemistry dominate in both samples (Fig. 5) as $\mathrm{C}_{27^{-}}$to $\mathrm{C}_{29}$-homologs. In addition, $\mathrm{C}_{26^{2}}$-norcholestanes (VI) were identified and also a $\mathrm{C}_{21}$-sterane, which may be pregnane (VII). The saturated triterpanes also increased relative to the triterpenes, although hop-17(21)ene (IX) and hop-13(18)-ene-II (X) are still present in fairly high amounts. Only small changes were observed with respect to the concentration of $17 \beta(\mathrm{H})$-hopanes (XIII) relative to the $17 \alpha(\mathrm{H})$-hopanes (XII). Apparently, the conversion of the former to the more stable $17 \alpha(\mathrm{H})$-isomers (van Dorsselaer et al., 1977) proceeds very slowly. As in the shallower samples, no moretanes (XIV) were detected.

\section{Aromatic Hydrocarbons}

The four shallowest samples (i.e., those from Lithologic Units 1 and 2) contain perylene (XV) as the most abundant aromatic hydrocarbon. Three thiophenes, for which structures XVI, XVII, and XVIII are tentatively assigned on the basis of their mass spectra, are the next most abundant components in the aromatic hydrocarbon fraction of Sample 467-13-4, 132-148 cm (116.4 m). Thiophenes are virtually absent in Sample 467-36-2, $133-150 \mathrm{~cm}$, but reappear in the Lithologic Unit 2 samples as a variety of alkyl- and dialkylthiophenes.

Aromatic steroid hydrocarbons are present in all four samples. Monoaromatic compounds with ring $\mathrm{C}$ aromatized (XIX) were identified on the basis of the intense $\mathrm{m} / \mathrm{z} 253$ fragment in their mass spectra (Schaeffle et al., 1978). Obviously a homologous series is present, but the elemental compositions could not be determined due to the absence of molecular ions. Diaromatic steroid hydrocarbons were not identified unambiguously, but triaromatic steroids (XX) are indicated on the basis of the $\mathrm{m} / \mathrm{z} 231$ mass chromatograms. Other major components in Lithologic Unit 2 samples were tentatively identified as ring $\mathrm{A}$ or ring $\mathrm{B}$ aromatized monoaromatic steroid hydrocarbons by interpretation of mass spectra (e.g., molecular ions and base peak at $\mathrm{m} / \mathrm{z} 211$ from possible ring $\mathrm{D}$ cleavage).

The two samples from Lithologic Unit 4 exhibit aromatic hydrocarbon compositions similar to more mature sediments. Perylene and the thiophenes identified in the shallower sediments are no longer dominant. Instead, various alkyl aromatics of different homologous series form the major portions of these fractions. Because of this complexity, the capillary chromatograms show a major unresolved hump. Mono-, di-, and triaromatic steroid hydrocarbons, however, are still 
467-36-2

$331.9 \mathrm{~m}$

Lower Pliocene

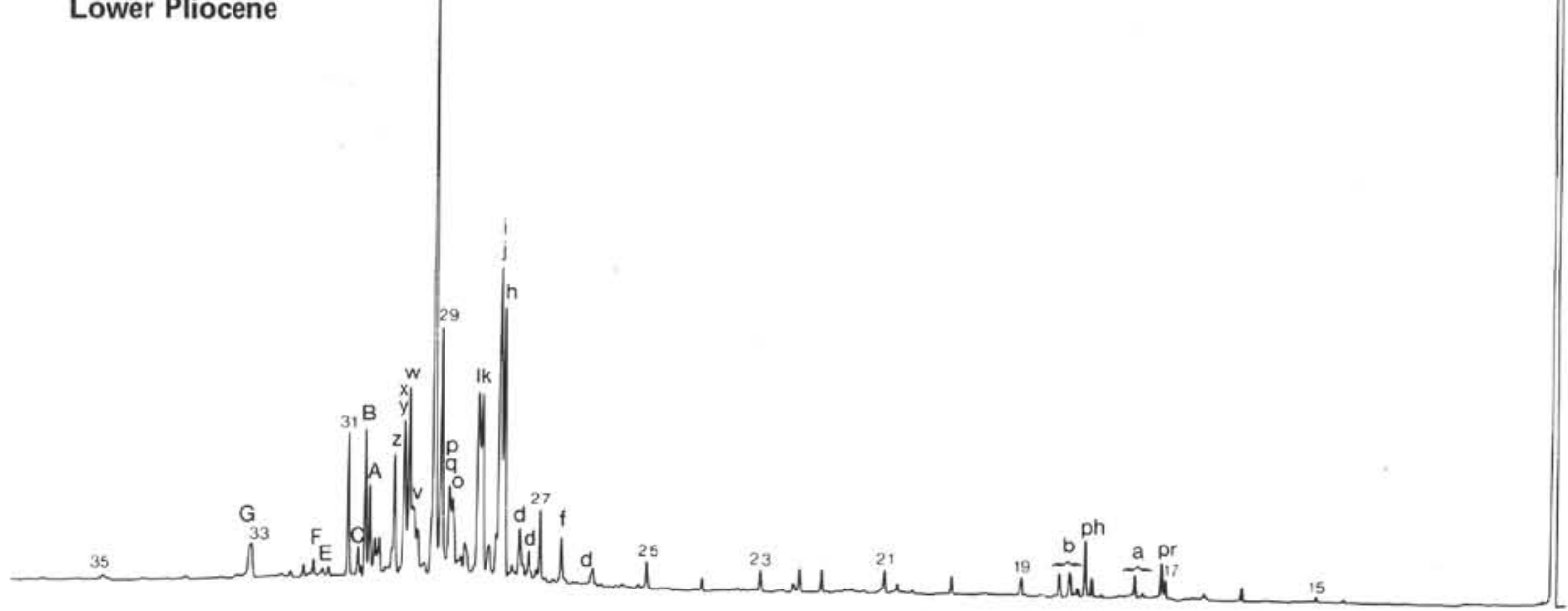

467-104-1

$976.5 \mathrm{~m}$

Middle Miocene
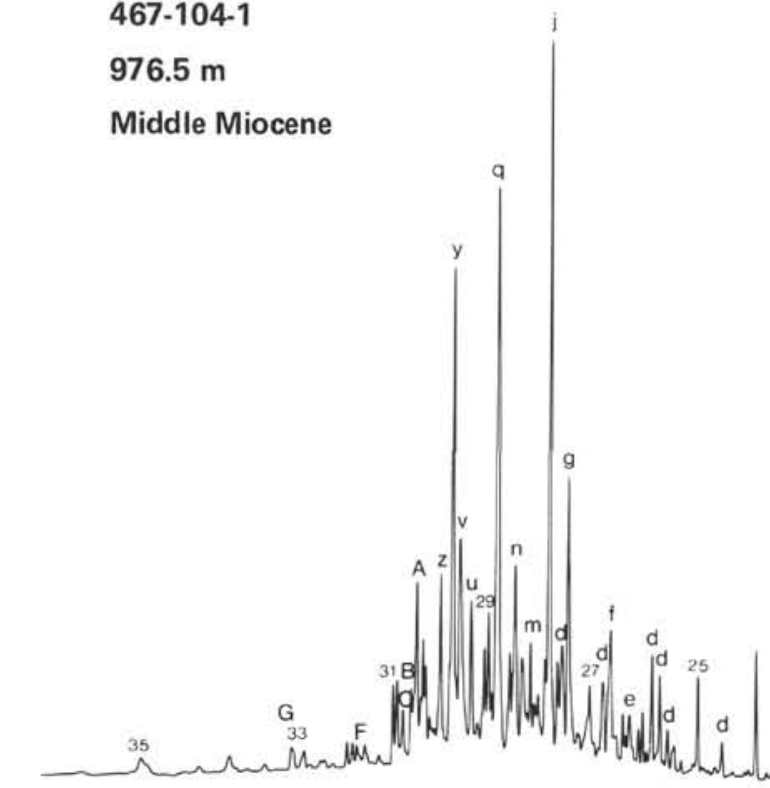

80

60

40

20

Retention Time ( $\mathrm{min})$

Figure 5. Capillary column gas chromatograms of the nonaromatic hydrocarbon fractions of two sections from DSDP Hole 467. ( $N$-alkanes are numbered. Compounds marked with letters were identified by GC/MS and are listed in Table 3 ).

highly concentrated at the high molecular weight end of the chromatograms.

\section{Fatty Acids}

GC/MS investigation of the fatty acid methyl esters of three samples from Sections 467-36-2, 467-97-2, and 467-104-1 revealed a dominance of fatty acids between $n-\mathrm{C}_{12}$ and $n-\mathrm{C}_{18}$, with the $n-\mathrm{C}_{16}$ acid as the most prominent component in each case. $N-\mathrm{C}_{20}$ to $n-\mathrm{C}_{26}$ fatty acids and possibly some branched acids are present in low concentrations. A very high predominance of even-car- bon-number acids was observed both in the low and high molecular weight part in all three samples.

\section{Microscopy}

All isolated kerogens of the samples from Hole 467 contain a background matter composed of clay minerals, pyrite, amorphous organic matter, and small, rounded to angular particles of less than $3 \mu \mathrm{m}$ diameter. The background matter forms the bulk of the kerogen concentrates (Fig. 6). Larger, structured particles used for maceral and reflectance measurements form only a 
Table 3. Isoprenoid, steroid, and triterpenoid hydrocarbons identified in the nonaromatic hydrocarbon fractions of Hole 467 samples.

\begin{tabular}{|c|c|c|c|c|c|c|c|c|}
\hline & \multirow[b]{2}{*}{ Compound(s) } & \multirow{2}{*}{$\begin{array}{c}\text { General } \\
\text { Structure }\end{array}$} & \multicolumn{6}{|c|}{ Core-Section } \\
\hline & & & $13-4$ & $36-2$ & $54-2$ & $63-2$ & $97-2$ & $104-1$ \\
\hline pr & pristane & & + & + & ++ & ++ & +++ & +++ \\
\hline & pristenes & & & + & + & + & & \\
\hline $\begin{array}{l}\text { ph } \\
\text { b }\end{array}$ & $\begin{array}{l}\text { phytane } \\
\text { phytenes }\end{array}$ & & + & $\begin{array}{l}+ \\
+\end{array}$ & $\begin{array}{c}+++ \\
+\end{array}$ & $\begin{array}{c}+++ \\
++\end{array}$ & +++ & +++ \\
\hline c & $\mathrm{C}_{21}$-sterane & VII & & & & & + & + \\
\hline d & rearranged sterenes & 1 & & + & + & tr & ++ & ++ \\
\hline & $5 \beta$-norcholestane & VI & & & & & + & + \\
\hline \multirow[t]{3}{*}{$\mathrm{f}$} & $5 \alpha$-norcholestane & VI & & + & & & ++ & ++ \\
\hline & cholesta-4,22-diene & IV & & tr & + & + & & \\
\hline & cholesta-5,22-diene & IV & & tr & + & + & & \\
\hline 8 & $5 \beta$-cholestane & $\mathrm{v}$ & + & tr & + & tr & ++ & +++ \\
\hline $\mathrm{h}$ & cholest-4-ene & II & +++ & +++ & +++ & +++ & + & \\
\hline & cholest-5-ene & III & +++ & +++ & +++ & +++ & + & \\
\hline & $5 \alpha$-cholestane & $\mathrm{v}$ & + & + & + & + & +++ & +++ \\
\hline k & 24-methylcholesta-4,22-diene & IV & ++ & ++ & +++ & ++ & & \\
\hline & 24-methylcholesta-5,22-diene & IV & ++ & ++ & +++ & ++ & & \\
\hline $\mathrm{m}$ & $17 \alpha(\mathrm{H})$-trisnorhopane & XII & + & + & + & + & + & + \\
\hline \multirow[t]{2}{*}{ n } & 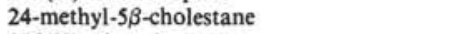 & $\mathrm{v}$ & + & $\operatorname{tr}$ & + & $\operatorname{tr}$ & ++ & ++ \\
\hline & $17 \beta(\mathrm{H})$-trisnorhopane & XIII & + & + & + & + & + & $\mathrm{tr}$ \\
\hline 0 & 24-methylcholest-4-ene & II & + & + & +++ & + & + & \\
\hline p & 24-methylcholest-5-ene & III & + & + & +++ & + & + & \\
\hline & 24-methyl-5 $\alpha$-cholestane & $\mathrm{v}$ & + & + & + & + & +++ & +++ \\
\hline $\mathrm{r}$ & $17 \alpha(\mathrm{H}), 18 \alpha(\mathrm{H}), 21 \beta(\mathrm{H})-28,30$-bisnorhopane & $\mathrm{XI}$ & ++ & +++ & ++ & + & & \\
\hline s & 24-ethylcholesta-4,22-diene & IV & + & tr & +++ & + & & \\
\hline $\mathrm{t}$ & 24-ethylcholesta-5,22-diene & IV & + & tr & +++ & + & & \\
\hline u & 24-ethyl-5 $\beta$-cholestane & $\mathrm{v}$ & + & tr & + & tr & ++ & ++ \\
\hline & $17 \alpha(\mathrm{H})$-norhopane & XII & + & + & + & + & ++ & ++ \\
\hline w & 24-ethylcholest-4-ene & II & +++ & ++ & +++ & +++ & + & \\
\hline $\mathrm{x}$ & 24-ethylcholest-5-ene & III & +++ & ++ & +++ & +++ & + & \\
\hline \multirow[t]{3}{*}{$\mathbf{y}$} & 24-ethyl-5 $\alpha$-cholestane & $\mathrm{v}$ & + & + & + & + & +++ & +++ \\
\hline & 4-methylsteranes & VIII & $\operatorname{tr}$ & tr & to & tr & + & + \\
\hline & $\mathrm{C}_{30}$-triterpene & & $\operatorname{tr}$ & tr & tr & tr & & \\
\hline$z$ & hop-17(21)-ene & IX & ++ & ++ & +++ & +++ & ++ & ++ \\
\hline A & $\begin{array}{l}C_{30} 0^{-t r i t e r p e n e} \\
17 \alpha(\mathrm{H}) \text {-norhopane }\end{array}$ & XII & $\begin{array}{l}\text { tr } \\
+\end{array}$ & $\begin{array}{l}t \\
+\end{array}$ & $\begin{array}{l}4 \\
+\end{array}$ & $\begin{array}{l}\text { tr } \\
+\end{array}$ & + & ++ \\
\hline B & hop-13(18)-ene-II & $\mathrm{x}$ & ++ & ++ & ++ & + & + & + \\
\hline & $17 \beta(\mathrm{H})$-norhopane & XIII & + & + & $\mathrm{tr}$ & tr & & \\
\hline & $\mathrm{C}_{30}$-triterpene & & tr & & + & + & & \\
\hline & $\mathrm{C}_{30}$-triterpene & & + & & & & & \\
\hline E & $17 \alpha(\mathrm{H})$-homohopane ( 2 isomers) & XII & + & + & $\operatorname{tr}$ & $\operatorname{tr}$ & + & tr \\
\hline \multirow[t]{2}{*}{$\mathrm{F}$} & $17 \beta(\mathrm{H})$-hopane & XIII & + & + & + & + & + & + \\
\hline & $17 \alpha(\mathrm{H})$-bishomohopane (2 isomers) & XII & + & + & & & $\operatorname{tr}$ & tr \\
\hline \multirow[t]{3}{*}{ G } & $17 \beta(\mathrm{H})$-homohopane & XIII & + & + & + & + & + & + \\
\hline & $17 \beta(\mathrm{H})$-bishomohopane & XIII & + & + & + & + & + & + \\
\hline & $\mathrm{C}_{32}-\mathrm{C}_{35}-17 \alpha(\mathrm{H})$-hopanes & XII & + & $\mathrm{tr}$ & & & & tr \\
\hline
\end{tabular}

Note: Compounds are listed in order of elution from the GC column (cf. Fig. 5); estimated relative abundances within each sample: $+++=$ major, $++=$ intermediate, $+=$ minor, $\mathrm{tr}=$ trace amounts.

minor part of the kerogens (Fig. 6) and are almost completely of detrital origin. The autochthonous, marine debris, mostly represented by algal filaments, is also present in a detrital form. Unicellular algal bodies or clearly identifiable algal colonies are rare in samples from Hole 467, although the amount of liptinitic material (as lipto-detrinite; Stach et al., 1975) is quite high (Fig. 6).

The bulk of the background matter, especially in the samples from Sections 467-13-4 and 467-36-2 (Lithologic Unit 1), is composed of nonfluorescent, unfigured, somewhat diffuse material with a reflectance in the range $0.17 \%$ to $0.4 \%$. These particles are often frayed at the edges and fissured. They may be humic gels comparable to the gelinite in brown coals (Cornford, 1979a). Section 467-63-2 (Lithologic Unit 2) lacks this material in its disseminated, dispersed form, and Sections 467-97-2 and 467-104-1 (Lithologic Unit 4) are depleted in humic gels, the background matter being dominantly of sapropelic (i.e., amorphous bituminous) nature.
The proportion of liptinitic matter in the kerogens from Lithologic Unit 1 (Sections 467-13-4 and 467-36-2) varies between $2 \%$ and $3 \%$ (Fig. 6) and makes up one third of all well-characterized particles. Section 467-63-2 (Lithologic Unit 2) exhibits the highest amount of particles and an absolute liptinite content comparable to the Lithologic Unit 1 samples (about 3\%). However, the large amount of eroded and reworked higher-reflecting particles (Fig. 7), as indicated by the presence of bimacerites, considerably lowers the ratio of liptinite to total particles to $10 \%$. The number of both vitrinite and inertinite particles is reduced in Lithologic Unit 4, but on the other hand the fluorescence of the background matter, dull in Unit 1 and very weak in Unit 2, becomes more intense. Apparently, Lithologic Unit 4 contains a more sapropelic type of organic matter, which is also evident from the high amount of pyrite in Samples $467-97-2,105-109 \mathrm{~cm}$ and $467-104-1,145-150 \mathrm{~cm}$. The coincidence of reduced liptinite content and intensely fluorescing background matter can be explained by the diagenetic transformation and disintegration of struc- 


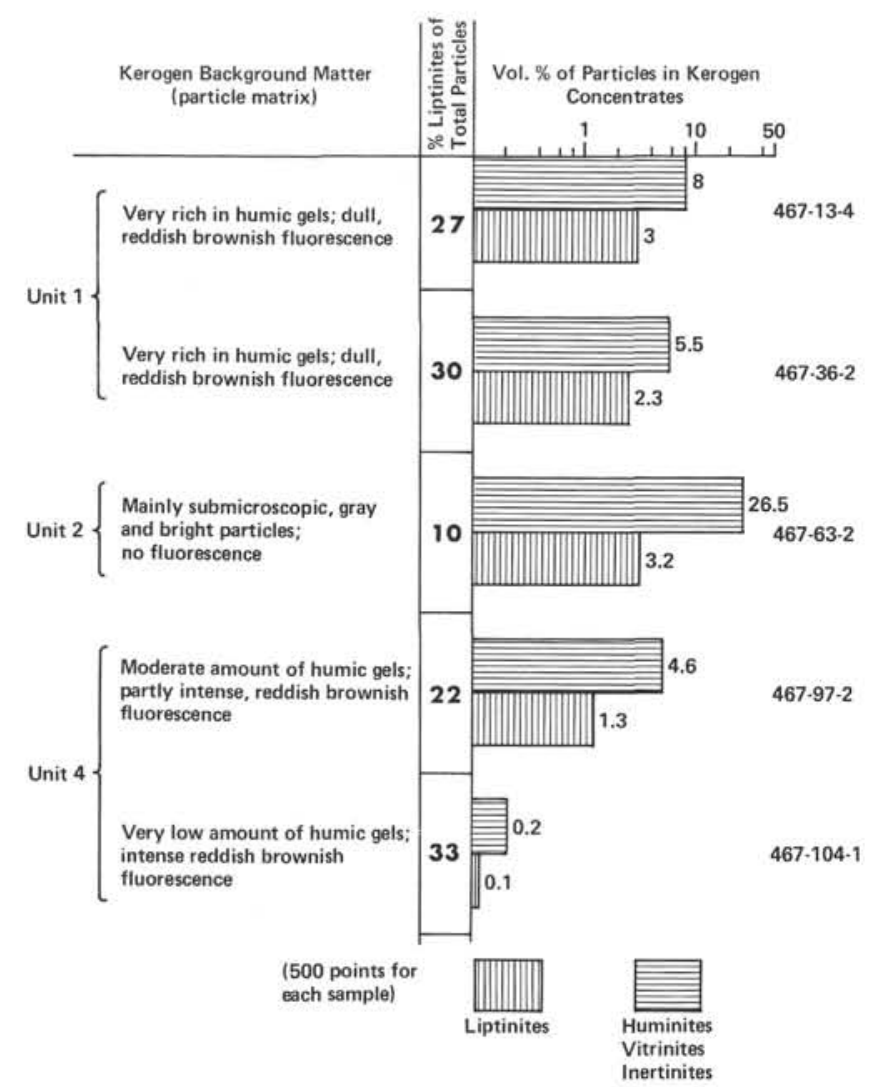

Figure 6. Amount and distribution patterns of structured organic particles larger than $3 \mu \mathrm{m}$ and characterization of kerogen matrix for five samples from DSDP Hole 467.

tured organic matter at increasing depth of burial (see the following).

Figure 7 shows the reflectance histograms (huminites, vitrinites, and inertinites larger than $10 \mu \mathrm{m}$ ) for Sections 467-13-4 (116.4 m), 467-63-2 (588.3 m) and 467-97-2 $(911.1 \mathrm{~m})$. Excluding the more vitrinite/inertinite-rich Section 467-63-2 (Fig. 6), differences mainly occur in the reflectance range below $0.6 \% \overline{\mathrm{R}}_{\mathrm{o}}$. This is consistent with a simultaneous increase in reflectivity and maturity at greater depths. The distributions in the higher reflectance range are very much alike. Particles in this range consist of oxidized and/or reworked organic matter. The similarity indicates that the overall composition of the eroded material remained constant in this area from middle Miocene to Pliocene. Section 467-63-1, containing a more coaly type of organic matter, is an exception in this series. The distribution in Figure 7 can be explained by an addition of obviously reworked vitrinitic organic matter. The inertinite contribution is less affected.

A tentative huminite/vitrinite reflectance trend with increasing depth is shown in Figure 8. Though standard deviations are fairly large, an increase of reflectance downhole is obvious; maximum reflectance at bottomhole depth approaches $0.5 \% \overline{\mathrm{R}}_{\mathrm{o}}$.
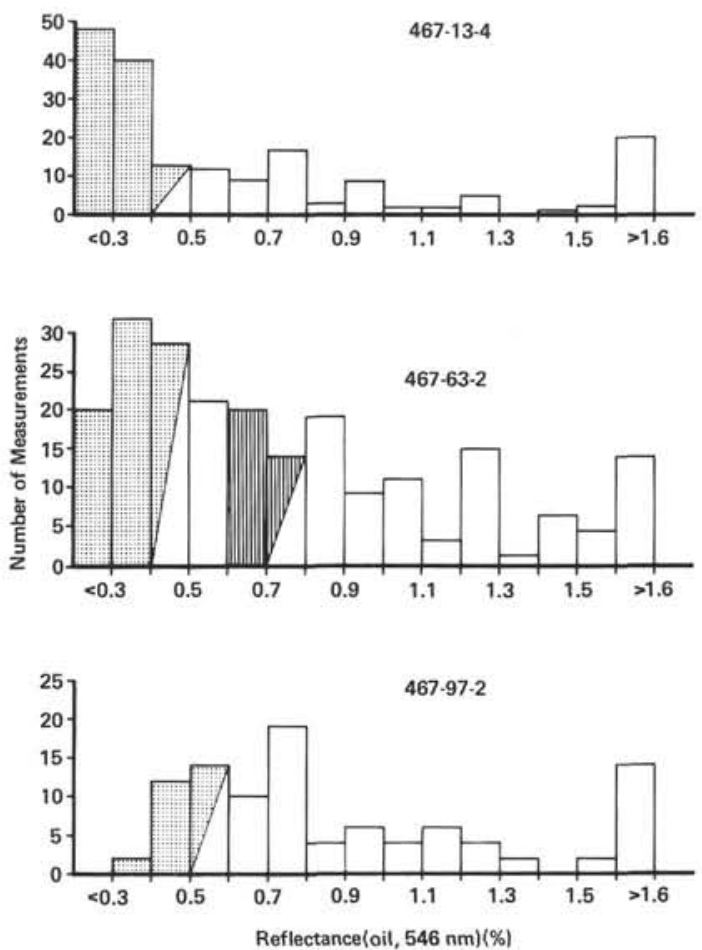

Huminite/vitrinite $\quad \square \|_{\begin{array}{l}\text { Rederived vitrinite } \\ \text { + inertinite }\end{array}}^{\text {Inertinite }}$

Figure 7. Reflectance histograms of huminites, vitrinites, and inertinites larger than $10 \mu \mathrm{m}$ in kerogen concentrates of three core samples from DSDP Hole 467. (Bimacerites exhibiting a vitrinite reflectance of $0.78 \%-0.83 \%$ are indicative of rederived organic material in Section 467-63-2.)

\section{Site 471, Off Baja California}

\section{Carbon Contents and Extractable Organic Matter}

The organic carbon contents of samples from Hole 471 are fairly constant down the hole. The absolute amounts are moderate and vary between $0.70 \%$ and $1.12 \%$ (Table 2). The highest carbonate carbon content $(0.57 \%)$ was measured for the shallowest samples (Pleistocene, $21.8 \mathrm{~m}$ ). In the Lithologic Unit 4 samples, the inorganic carbon content is very low and follows the organic carbon variations (Fig. 9).

The amount of extractable organic matter is low in the samples from Lithologic Units 1 and $2(7 \mathrm{mg} / \mathrm{g}$ $C_{\text {org }}$ ). In samples from Lithologic Unit 4 the extract yields steadily increase with depth from $11 \mathrm{mg} / \mathrm{g} \mathrm{C}_{\text {org }}$ to $37 \mathrm{mg} / \mathrm{g} \mathrm{C}_{\text {org }}$ (Fig. 9, Table 2).

\section{Rock-Eval Pyrolysis}

In the hydrogen index versus oxygen index diagram (Fig. 3), the Hole 471 samples are closer to the kerogen type III line than are the samples from Hole 467. This indicates that at Site 471 the contribution of terrigenous and/or inert reworked organic matter was somewhat higher than at Site 467 . This led to a considerable di- 


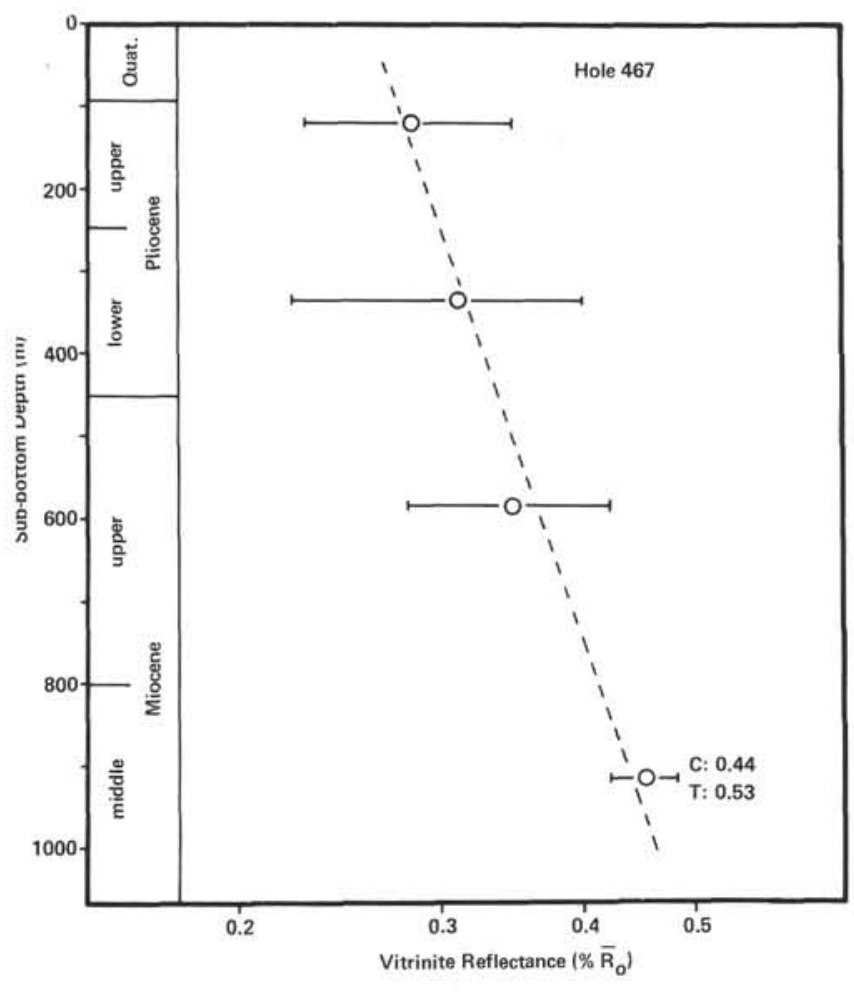

Figure 8. Vitrinite reflectance trend for DSDP Hole 467 samples. (The figure shows arithmetic means and standard deviations; $C=$ collinite, $\mathrm{T}=$ telinite.)

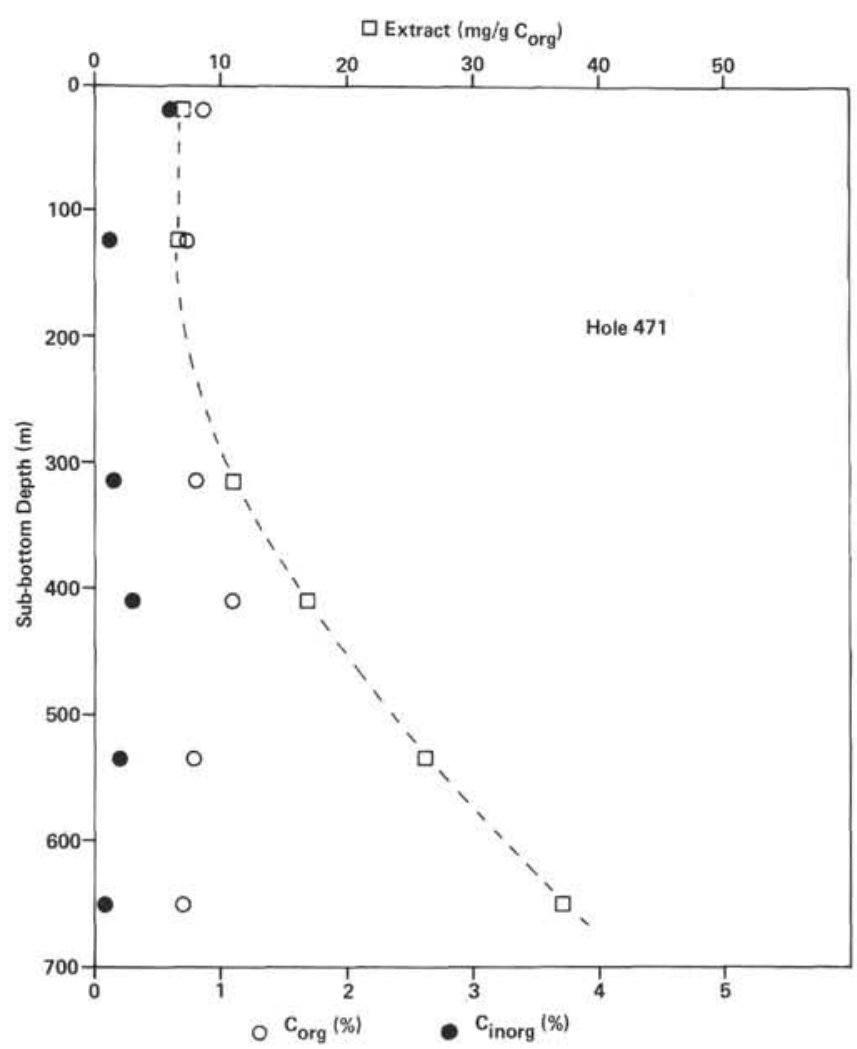

Figure 9. Organic and inorganic carbon contents and trend of increasing extractable organic matter with depth for DSDP Hole 471 samples. lution of the autochthonous type II kerogens (cf. Rouchaché et al., 1979).

\section{Nonaromatic Hydrocarbons}

The $n$-alkane and isoprenoid hydrocarbon distributions are shown in Figure 10. Except for the deepest sample (471-69-3, 135-150 cm) a predominance of longchain $n$-alkanes with maxima at $n-\mathrm{C}_{29}$ or $n-\mathrm{C}_{31}$ and a high odd-carbon-number preference is obvious in all samples. The relatively large amount of $n$-alkanes below $n-C_{25}$ in Sample $471-3-2,120-137 \mathrm{~cm}$ is possibly the result of contamination. In all samples phytane dominates over pristane, although this predominance is considerably more pronounced in the deepest three samples. Within the series of these three samples the increase of $n$-alkanes below $n-\mathrm{C}_{27}$ and the decrease of the odd/even predominance and the phytane/pristane ratio may indicate the onset of thermal hydrocarbon production.

The GC/MS analysis of the nonaromatic hydrocarbon fractions revealed the presence of numerous saturated and unsaturated cyclic hydrocarbons (Table 4). The most important compounds are marked in the capillary column gas chromatograms of three selected samples (Fig. 11). The uppermost two samples (from Lithologic Units 1 and 2) are relatively lean in saturated cyclic hydrocarbons, and no unsaturated compounds were detected except some traces of rearranged sterenes (I) in Sample 471-3-2, 120-137 cm. Hopanes from the $17 \alpha(\mathrm{H})$-series (XII) are the most abundant cyclic hydrocarbons, but some $17 \beta(\mathrm{H})$-hopanes (XIII) and moretanes (XIV) were also found (Table 4; Fig. 11, top). Minor amounts of steranes are from the normal $5 \alpha$ - and $5 \beta$-series (V) with the $\mathrm{C}_{29}$-compound being more abundant than $\mathrm{C}_{27}$ - and $\mathrm{C}_{28}$-homologs.

The Lithologic Unit 4 samples contain a dominance of steroid hydrocarbons. Unsaturated compounds are of major importance in Samples 471-34-2, 103-107 cm (Table 4) and 471-44-1, 110-118 cm (Fig. 11, middle), and fully saturated steranes predominate in the deepest samples (Table 4; Fig. 11, bottom). Sterenes and steradienes in Sections 471-34-2 and 471-44-1 are $\Delta^{4}$ - and $\Delta^{5}$-isomers, as described for the Hole 467 samples (see the preceeding material). Rearranged sterenes are less abundant (Fig. 11, middle). Small amounts of $5 \alpha$ - and $5 \beta$-steranes in the range of $\mathrm{C}_{26}$ to $\mathrm{C}_{29}(\mathrm{~V}, \mathrm{VI})$ are present in Sample 471-34-2, 103-107 cm; a relative increase in abundance of these compounds was observed in Sample 471-44-1, 100-118 cm.

Rearranged sterenes (I) are the only unsaturated steroid hydrocarbons in Samples 471-57-3, 100-126 cm (Table 4) and 471-69-3, 135-150 cm (Fig. 11, bottom). Normal steranes (V, VI) in these samples range from $\mathrm{C}_{26}$ to $\mathrm{C}_{29}$, with the major $\mathrm{C}_{28}$-compound being slightly more abundant than the $\mathrm{C}_{27}$ - and $\mathrm{C}_{29}$-homologs. In addition, small amounts of a $\mathrm{C}_{21}$-sterane (VII) and various 4-methylsteranes (VIII) are present in all samples from Lithologic Unit 4.

Hop-17(21)-ene (IX) and hop-13(18)-ene-II (X) are the most important triterpenes in all samples from Lithologic Unit 4. Saturated triterpanes are mainly from 

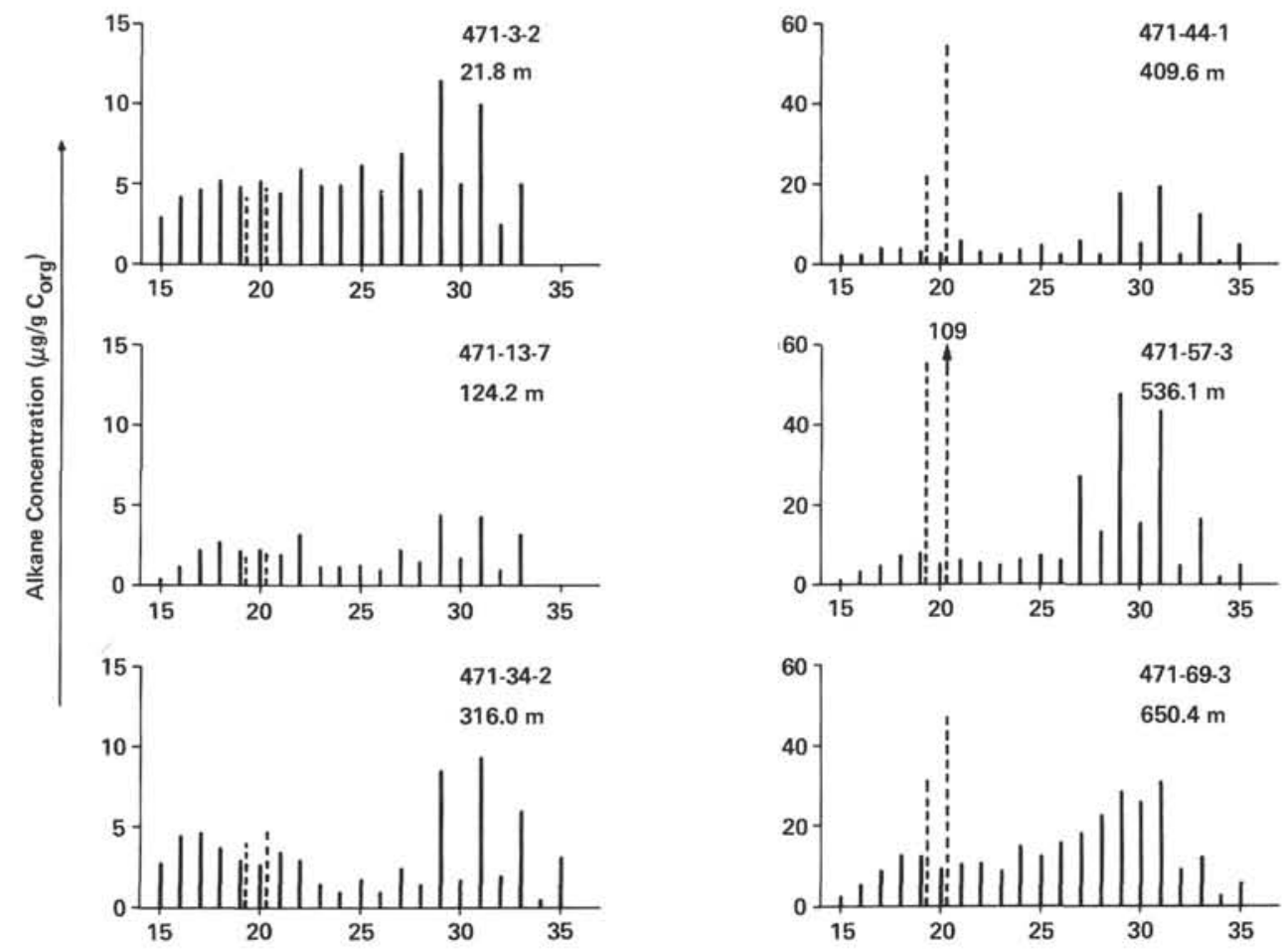

Carbon Number

Figure 10. $\mathrm{N}$-alkane (solid lines) and isoprenoid hydrocarbon (dotted lines) distributions (absolute concentrations) for DSDP Hole 471 samples. (Note different vertical scales on left- and right-hand sides.)

the $17 \alpha(\mathrm{H})$-hopane series $(\mathrm{XII})$, but $17 \beta(\mathrm{H})$-hopanes (XIII; decreasing concentration with depth) and moretanes (XIV) are also present.

\section{Aromatic Hydrocarbons}

Unsubstituted aromatic hydrocarbons, which most probably originate from combustion-generated airborne particulates (Blumer and Youngblood, 1975), dominate in Sample 471-3-2, 120-137 cm. Phenanthrene, fluoranthene, and pyrene are the most abundant compounds identified, while perylene (XV) and alkyl-substituted aromatic hydrocarbons are found in much smaller concentrations. Perylene (XV) is, however, the dominant component in Sample 471-13-7, 112-130 cm from Lithologic Unit 2.

The relative amount of perylene (XV) in the four samples from Lithologic Unit 4 steadily decreases with depth. At the same time the concentration of alkylsubstituted aromatic hydrocarbons increases. Alkyl thiophenes, which are abundant in most samples from Hole 467 , were only tentatively identified in very small amounts in the two shallowest samples from Lithologic Unit 4. Aromatic steroid hydrocarbons are present in all four samples. Monoaromatic steroids are much more abundant than their di- and triaromatic counterparts, but there is a slight increase in the polyaromatic steroids with depth. Ring $\mathrm{C}$ aromatized monoaromatic steroids (XIX) were found as well as ring A and/or ring B aromatized analogs. There seems to be a trend of increasing generation, or favored preservation, of ring $\mathrm{C}$ aromatized monoaromatic steroid hydrocarbons (XIX) with depth relative to the ring $\mathrm{A}$ or ring $\mathrm{B}$ aromatized compounds.

\section{Fatty Acids}

Two samples from Hole 471 (471-57-3, 100-126 cm and $471-69-3,135-150 \mathrm{~cm}$ ) were analyzed for fatty acids. The distributions of their methyl esters as determined by GC/MS are similar to those reported for Hole 467 samples (i.e., fatty acids between $n$ - $\mathrm{C}_{12}$ and $n$ - $\mathrm{C}_{18}$ are dominant, with the $n-\mathrm{C}_{16}$ homolog being the most abundant compound in both samples). Long-chain fatty acids were observed as minor components only. Evencarbon-number acids are highly predominant over the whole range.

\section{Microscopy}

The main difference between the Hole 471 and Hole 467 kerogen samples is a considerably lower content of structured liptinites in the former, which indicates a relatively higher contribution of terrestrial and/or reworked organic matter. The sample from Lithologic Unit 2, an exception from this general scheme, is fairly similar to the samples from Unit 1 in Hole 467 with respect to background matter, total particle content, and amount of liptinites (Fig. 12). Apart from this sample, fluorescence of background matter is not observed (Section 471-3-2), very weak (Section 471-69-3), or yellowish to greenish (Sections 471-34-2 and 471-44-1). Section 471-44-1 is especially enriched in yellow greenish 
Table 4. Isoprenoid, steroid, and triterpenoid hydrocarbons identified in the nonaromatic hydrocarbon fractions of Hole 471 samples.

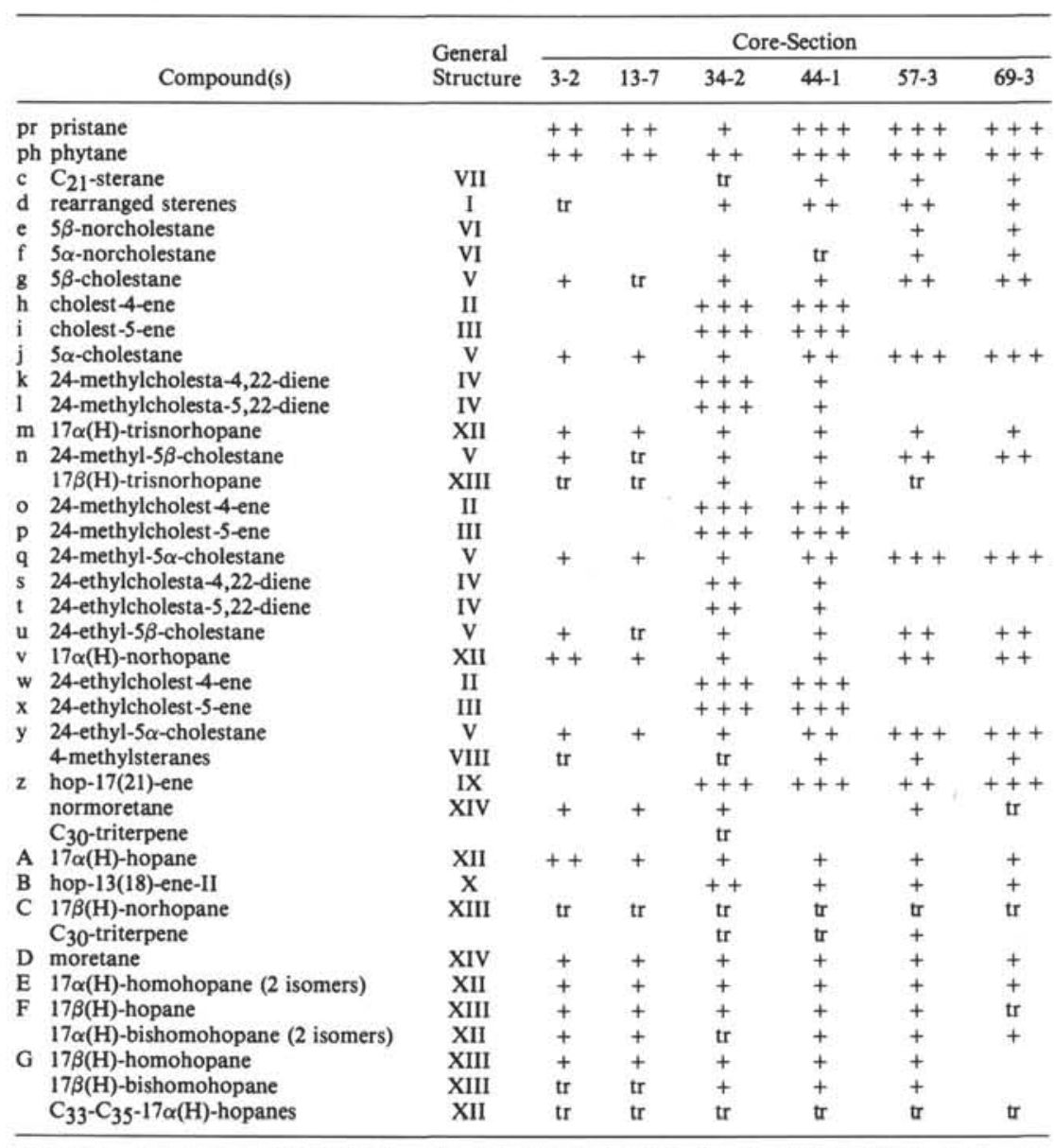

Note: Compounds are listed in order of elution from the GC column (cf. Fig. 11); estimated relative abundances within each sample: $+++=$ major,$++=$ intermediate,$+=$ minor, $t r=$ trace amounts

fluorescing bitumen that may originate from waxy and resinous plant constituents and is typical for sediments of low maturity (Jacob, 1974).

A downhole huminite/vitrinite trend is shown in Figure 13. The reflectance of huminites in Sample 471-34-2, $103-107 \mathrm{~cm}(316.0 \mathrm{~m})$ is in the range of $0.25 \%$ to $0.41 \%$, with a pronounced maximum around $0.35 \%$. Determination of the mean reflectance value $(0.34 \%)$ in this sample was facilitated by the nearly complete lack of higher-reflecting (oxidized) particles. Section 47169-3 (650.4 m) contains a dominance of huminites in the reflectance range $0.35 \%$ and $0.44 \%$, which results in an arithmetic mean of $0.40 \%$. This is in good agreement with some clearly identifiable semi-fusinites of $0.61 \%$ to $0.64 \%$ reflectance, which are always observed at a reflectance value of $0.2 \%$ higher than are the corresponding vitrinites $(\mathrm{H}$. W. Hagemann, personal communication, 1980.).

\section{DISCUSSION}

\section{Amount and Type of Organic Matter}

The results of the organic geochemical and petrographic investigations of the DSDP Leg 63 core samples indicate that the environmental conditions at Sites 467 and 471 in general favored the preservation of organic matter throughout the time span covered, i.e. from middle Miocene to present. High organic carbon contents, which exceed $3 \%$ in the upper 500 meters of the sediment section at Site 467 , together with molecular parameters (e.g., high phytane concentrations), suggest that during sedimentation anoxic conditions prevailed in the upper sediment layers and perhaps in the water column above. Preservation of organic matter is not favored in deep ocean waters (McIver, 1975). There are mechanisms, however, which allow sediments rich in organic matter to be deposited at great water depths (Welte et al., 1979). Examples are the barred basin situation of the Black Sea (Ross et al., 1978), the sediment mass flows down the continental slope associated with an oxygen-minimum layer at the shelf edge off northwestern Africa (Cornford et al., in press; and references therein), and the formation of Cretaceous black shales in the northeastern Atlantic Ocean, which is not readily explained at the moment but may be due to local anoxic environments caused by extensive deltaic influx of organic matter (e.g., Arthur, 1979; Cornford et al., in press).

At Site $\mathbf{4 6 7}$ in the San Miguel Gap, which is a small embayment at the rise of the outer California Conti- 

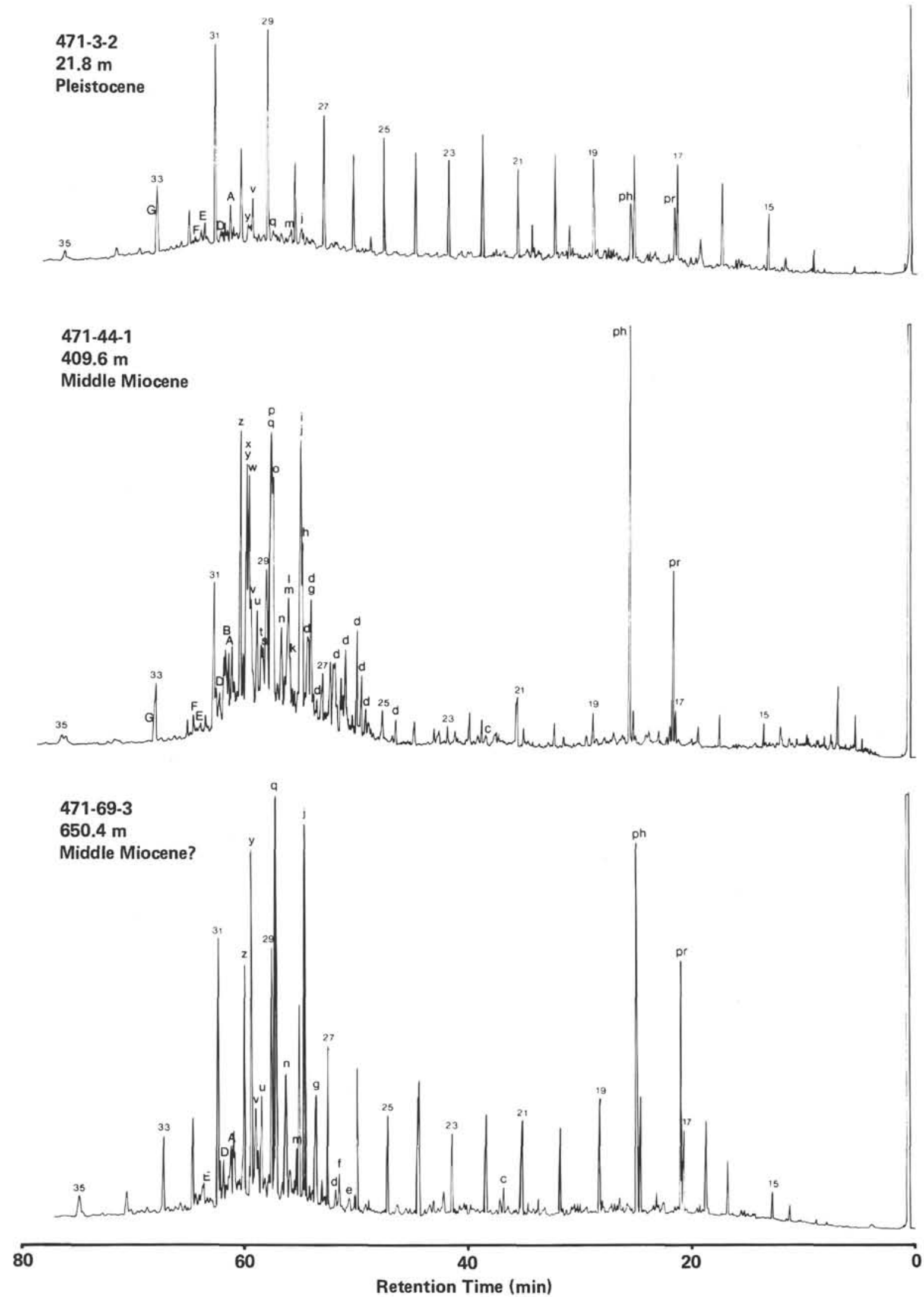

Figure 11. Capillary column gas chromatograms of the nonaromatic hydrocarbon fractions of three samples from DSDP Hole 471. ( $N$-alkanes are numbered. Compounds marked with letters were identified by GC/MS and are listed in Table 4.) 


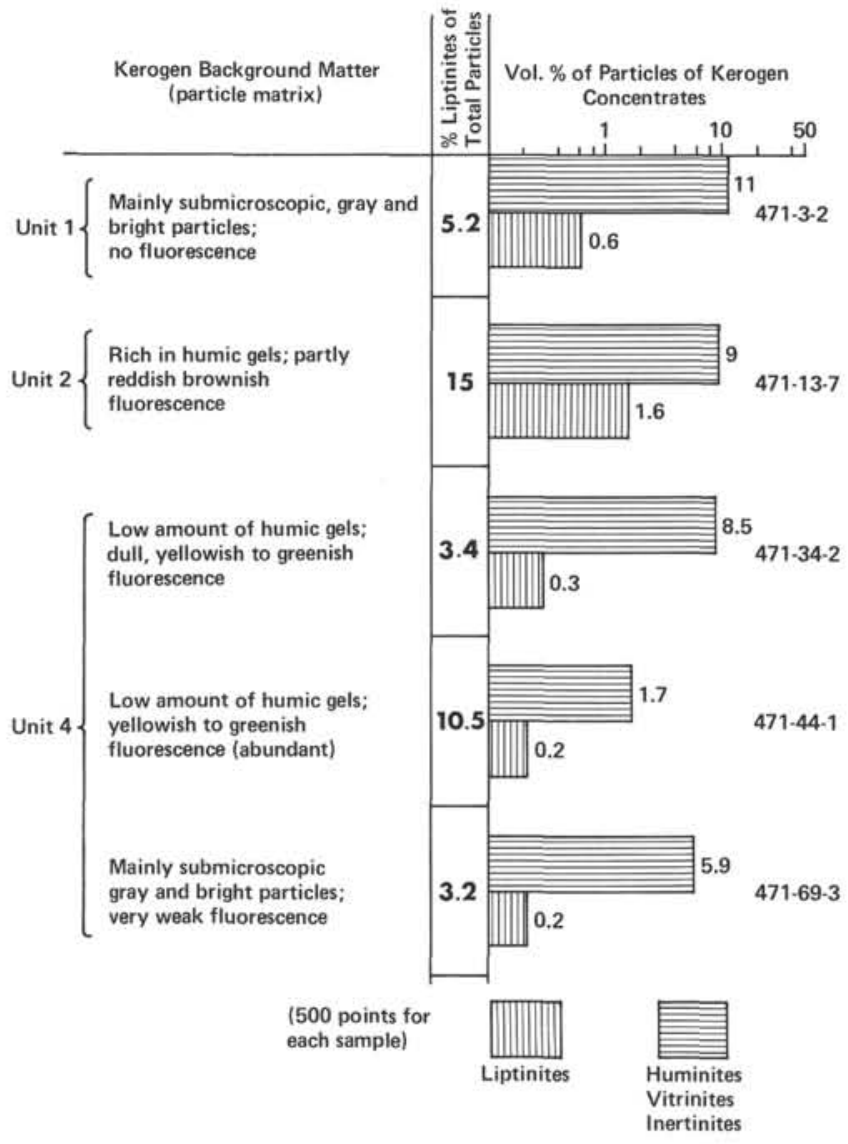

Figure 12. Amount and distribution patterns of structured organic particles larger than $3 \mu \mathrm{m}$ and characterization of kerogen matrix for five samples from DSDP Hole 471.

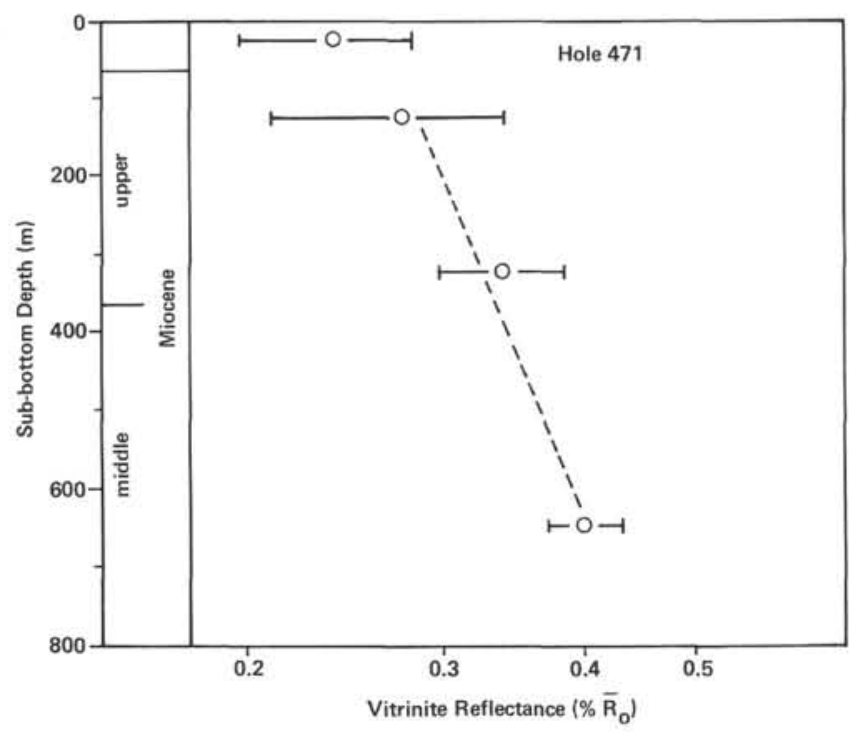

Figure 13. Vitrinite reflectance trend for DSDP Hole 471 core samples. (The figure shows arithmetic means and standard deviations.) nental Borderland, slumping and turbidite mass flows are only observed to a minor extent in the sections penetrated (see the Site 467 chapter, this volume). It is unlikely that this factor can account for the high organic carbon contents, especially in Lithologic Units 1 and 2. It thus seems possible that a local body of oxygendepleted water in the San Miguel Gap, a product of restricted water circulation, has to be considered as a factor responsible for the preservation of organic matter at Site 467. In contrast to this, extensive distal turbidite flows at Site 471 have transported organic matter to the deep-water environment and prevented oxidative destruction by rapid burial. At the same time, the transportation of large amounts of sands to this site results in a decrease of organic matter concentration as a result of dilution.

A first indication of the type of organic matter is gained from the results of the Rock-Eval pyrolysis (Fig. 3). All kerogens apparently are mixed type II/type III (cf. Roucaché et al., 1979). Apparently marine organic matter is associated and mixed with terrestrial higherplant debris. The relative contribution of the latter component is considerably higher at Site 471 than at Site 467. The results of the microscopic kerogen investigation are in good agreement with this interpretation. Furthermore they allow more detailed characterization of the type of organic matter. The samples from Lithologic Unit 1 of Hole 467 (Samples 467-13-4, 132-148 cm and 467-36-2, 133-150 cm) and Unit 2 of Hole 471 (Sample 471-13-7, 112-130 cm) revealed a mixture of predominantly humic matter and marine organic debris together with some vitrinitic and inertinitic material, which correlates well with a high to moderate oxygen and moderate hydrogen index in the Rock-Eval diagram (Fig. 3). Within this group, the sample from Section 471-13-7 exhibits the lowest content of liptinites and consistently the lowest hydrogen index. A second grouping is formed by the more sapropelic (bituminous) kerogens of Unit 4 samples from Hole 467. They are characterized by the absence (Sample 467-104-1, 145-150 cm) or low concentration (Sample 467-97-2, 105-109 cm) of humic gel and a high liptinite content (mostly amorphous). This corresponds to relatively high hydrogen and low oxygen indices from pyrolysis (Fig. 3). Samples with low contents of figured and/or amorphous liptinites and high amounts of land plant and oxidized organic material form a third group comprising the Hole 471 samples (except from Lithologic Unit 2) and Sample 467-63-2, 130-133 cm. An outstandingly high oxygen index, which probably is related to a higher inertinite content relative to the other samples, was found for Samples 467-63-2, 130-133 cm and 471-3-7, 120-137 cm (Fig. 3).

The similarity of the distribution of rederived organic matter in samples from Lithologic Units 1 and 4 of Hole 467 (Fig. 7) indicates a rather constant source for this material over about the last 15 m.y. A different source should be responsible for the vitrinitic matter in Sample 467-63-2, 130-133 cm (Lithologic Unit 2). 
A correlation of geochemical with petrographic data can also be discerned from the $n$-alkane patterns. High influx of terrigenous organic matter should yield high amounts of odd-numbered $n$-alkanes in the range of $n-\mathrm{C}_{27}$ to $n-\mathrm{C}_{33}$ (Eglinton and Hamilton, 1963). A plot of liptinite percentage versus concentration (normalized to organic carbon) of odd-numbered $n$-alkanes in that range clearly shows a negative correlation (Fig. 14). This diagram also demonstrates that the liptinite enrichment is much higher in Hole 467. For samples from both holes, this enrichment is generally due to marine organic matter and not to liptinites from terrestrial higher plants (e.g., pollen, spores). An exception is Sample 471-44-1, $100-118 \mathrm{~cm}$, described above as enriched in waxy and resinous amorphous bitumen. This accumulation of terrestrial higher-plant lipids falls off the trend, toward higher amounts of typical land-derived hydrocarbons (Fig. 14).

The contribution of some terrigenous organic matter to Sites 467 and 471 is indicated by the presence of longchain $n$-alkanes $\left(\mathrm{C}_{25}\right.$ to $\left.\mathrm{C}_{35}\right)$ with strong predominance of odd carbon numbers. The highest absolute amount of these $n$-alkanes at Site 467, in Section 467-63-2 (Fig. 4 ), correlates with the highest relative concentration of vitrinitic kerogen particles. The dominance of perylene (XV) in the samples from Lithologic Units 1 and 2 at both sites provides further evidence for the presence of terrigenous organic matter deposited under reducing conditions (Aizenshtat, 1973). Apparently, no major amounts of aromatic hydrocarbons are contributed by the marine organisms or formed from their remains at this very early stage of diagenesis. At Sites 467 and 471,

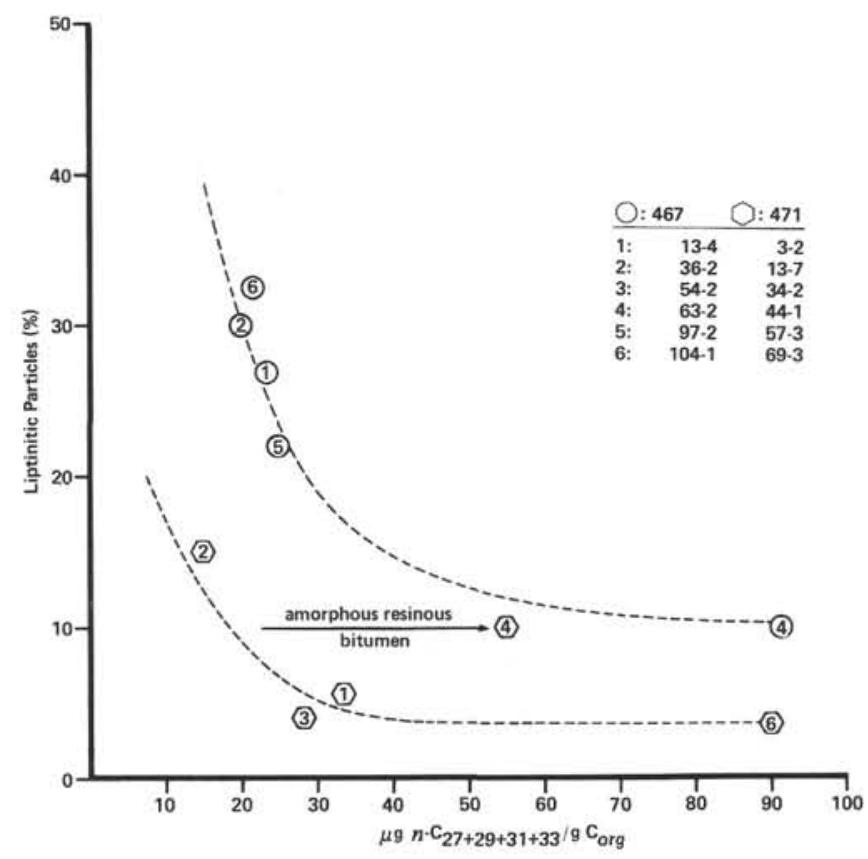

Figure 14. Relationship between amount of long-chain $n$-alkanes normalized to organic carbon and liptinite particles (relative to total amount of structured particles) in DSDP Holes 467 and 471 samples. perylene (XV) loses its dominance only in Lithologic Unit 4, where the production of new aromatic hydrocarbons increases considerably with depth.

Nothing can be said at present about the origin of the alkylated thiophenes, which were detected in Lithologic Units 1 and 2 at Site 467, with increasing yields downhole. It is interesting, however, that they are not found in similar concentrations in the Hole 471 samples. Thus they possibly are related to the higher contribution of marine organic matter at Site 467.

Steroid hydrocarbons form the major part of the branched/cyclic nonaromatic hydrocarbons in all samples from Hole 467 and all but the two shallowest samples from Hole 471 . The presence of the $\mathrm{C}_{26}$-steranes may be related to the unique appearance of $\mathrm{C}_{26}$-sterols in marine organisms (Djerassi et al., 1979). The distribution of the $\mathrm{C}_{27^{-}}$to $\mathrm{C}_{29}$-homologs, with the $\mathrm{C}_{27}$ compounds being more abundant than the $\mathrm{C}_{28^{-}}$and $\mathrm{C}_{29}$-steroid hydrocarbons, is characteristic of marine sediments containing organic matter from planktonic sources (Huang and Meinschein, 1979). This is true for the saturated steranes in the deepest samples as well as for the sum of the regular sterenes and steradienes in the shallower samples (Figs. 5 and 11).

The compositions of the unsaturated steroid hydrocarbons closely resemble those observed in slumped and turbiditic sediment sequences drilled during DSDP Leg $47 \mathrm{~A}$ at the northwest African continental rise south of the Canary Islands (Cornford et al., 1979), Leg 50 off Morocco (J. Rullkötter et al., in press) and Legs 56/57 in the Japan Trench (Rullkötter et al., 1980). As in these cases, only the ster-4-enes and ster-5-enes and the corresponding dienes were observed, but not the ster-2enes, which are believed to be the first hydrocarbon intermediates during diagenetic conversion of steroids to steranes (Dastillung and Albrecht, 1977). If this general transformation procedure holds true for the slumped and turbiditic sediments, it must be assumed that these are acidic enough to catalyze complete isomerization of ster-2-enes to ster-4-enes and ster-5-enes, but do not further catalyze conversion to rearranged sterenes (Rubinstein et al., 1975), because these are only minor constituents in all samples analyzed.

During mass transport by slumping or turbidity currents, rapid burial reduces the possibility of microbial degradation that plays a prominent role in the first conversion step of biolipids to geolipids (e.g., sterol to stanol transformation; Gagosian et al., 1979 and references therein). Thus a different mechanism involving direct removal of the sterol hydroxyl group may be involved in the formation of the ster-4-enes and ster-5enes.

Aromatic steroid hydrocarbons have been detected in increasing amounts with depth. In the monoaromatic compounds, aromatization has occurred in ring A or B and ring $\mathrm{C}$, respectively. Diaromatic steroid hydrocarbons are generally minor constituents, but relatively more triaromatic steroid hydrocarbons were found. A more detailed study is needed, however, to decide if these aromatic species are partly or mainly formed from 
sterenes and steradienes or if there is a different diagenetic route leading from sterols directly to aromatic hydrocarbons.

Hop-17(21)-ene (IX) is the most abundant triterpenoid hydrocarbon in the Leg 63 samples and was detected in the nonaromatic hydrocarbon fractions of all samples except the two shallowest ones from Hole 471 (Tables 3 and 4). Hop-17(21)-ene (IX) was described as a constituent of the Messel oil shale (Kimble et al., 1974), where it is the dominant nonaromatic cyclic hydrocarbon (J. Rullkötter, unpublished results). The composition of the extractable organic matter in the Messel shale suggests a significant microbial contribution (Kimble et al., 1974); thus hop-17(21)-ene may be of similar origin in the Leg 63 samples. Hop-13(18)-eneII (X), though it was found in ferns (Ageta et al., 1968), may also be a conversion product of hop-17(21)-ene (Ensminger, 1977) and thus be related primarily to a bacterial origin. Further evidence for the contribution of bacterial microorganisms may be gained from the relatively high concentration of extended $17 \beta(\mathrm{H})$-hopanes (XIII) (Ourisson et al., 1979). Other triterpenoid hydrocarbons, especially the $17 \alpha(\mathrm{H})$-hopanes (XII), are probably introduced into the sediments by transport of allochthonous, partly eroded, and recycled organic matter, because they already appear as saturated components in the shallowest samples.

Finally, the fatty-acid distributions, which were determined for a limited number of samples only, are consistent with a high contribution of marine organic matter, especially at Site 467 . Long-chain fatty acids characteristic of higher plants (e.g., Hitchcock and Nichols, 1971) are minor constituents. Iso- and anteiso fatty acids, which are generally considered to be indicators of bacterial origin (e.g., Boon et al., 1975), could not be identified unambiguously.

Summarizing these observations, deposition of organic matter under anoxic conditions favoring preservation of this labile material is a prominent feature of the sediments at DSDP Sites 467 and 471 . Autochthonous marine organic matter is mixed in varying concentrations with terrestrial higher-plant debris, which was transported to these sites from the nearby continent, and with the remains of bacterial biomass. In addition, reworked organic particles were detected but in many cases could not be differentiated from primary particles that were oxidized during distal transport. In general, the influence of terrigenous organic matter is higher at Site 471 than at Site 467 . This general pattern has not changed for each site from middle Miocene to Pleistocene, although the detailed investigations have revealed some variations.

\section{Maturity}

The kerogen maturity was determined by measurement of the huminite/vitrinite reflectance of the lowestreflecting assemblage of huminite/vitrinite particles. The results in Figures 8 and 13 show that a mean reflectance of nearly $0.5 \%$ may be extrapolated to bottomhole depth at both sites, which is at about 1000 meters for Hole 467 and about 700 meters for Hole 471. This is a considerably higher increase of maturity with depth than determined at the passive margin of the eastern North Atlantic. Mean vitrinite reflectance values of $0.5 \%$ were determined for the primary organic matter at 1450 meters for DSDP Site 397 (Cornford et al., 1979) and at 1700 meters for Site 398 (Cornford, 1979a), and only $0.45 \%$ were measured at 1600 meters for Sites 415 and 416 (Cornford, 1979b). In the Japan Trench (DSDP Legs 56/57) a slightly higher gradient was observed, which led to an extrapolated value of $0.5 \%$ vitrinite reflectance at 1300 meters depth, though the primary nature of the vitrinite organic matter was in question at this site (Rullkötter et al., 1980).

Increasing maturity with depth is also obvious from Figures 2 and 9, which show the amounts of extractable organic matter relative to organic carbon at different depth levels. At Site 467 the extract values remain constant down to about 600 meters sediment depth (despite some compositional variations evident from microscopy and pyrolysis results) and show a threefold increase between 600 and 1000 meters (Fig. 2). This increase of extract yield may be interpreted as an effect of increasing temperature and thus maturity. A similar observation was made at Site 471 (Fig. 9). Here the extract yields start to increase at about 300 meters depth and are higher by a factor of three to four in the lowest sample. As the chromatographic separation did not exhibit a clear trend in the composition of the extractable organic matter, the compounds released from the kerogens at increasing temperatures may at first be mainly heterocompounds produced by cleavage at heteroatomic bonds, with only some hydrocarbons. At both sites, the microscopic data show the lowest contents of structured liptinites at depths where a significant mobilization of bitumen occurs. A decrease of structured liptinites and increase of diffuse, amorphous liptinitic matter is especially pronounced in Hole 467 and may be partly a result of progressive degradation and transformation of structured liptinitic particles with increasing depth of burial.

A maturation trend is also observed in the hydrocarbon fractions. The most striking feature is the increasing saturation of the steroid hydrocarbons toward the lowermost samples (Figs. 5 and 11, Tables 3 and 4). The $n$-alkanes are less affected, but in Samples 467 97-2, 105-109 cm (911.1 m) and 467-104-1, 145-150 cm $(976.5 \mathrm{~m})$, the two deepest samples from Hole 467 , and in Sample 471-69-3, 135-150 cm (650.4 m), the deepest sample from Hole 471 , the $n$-alkane distributions appear somewhat smoother than at shallower depths (Figs. 4 and 10). The aromatic hydrocarbons show an increase in relative concentration of various homologous alkylated aromatics, which approach a petroleumlike distribution in the lowermost samples at both sites. The changes in the composition of the aromatic steroid hydrocarbons with depth cannot be readily interpreted at the moment. Surprisingly, the deepest samples also contain considerable amounts of $17 \beta(\mathrm{H})$-hopanes (XIII), and there is no drastic depth trend due to conversion into the more stable $17 \alpha(\mathrm{H})$-hopanes (XII; van Dorsselaer et al., 1977), which would parallel the conversion of sterenes to steranes. This may indicate that the two pro- 
cesses proceed at different rates and thus may be taken as overlapping molecular maturation parameters.

The rapid increase of maturity with depth is in agreement with the observed high geothermal gradient $\left(70^{\circ} \mathrm{C} /\right.$ $\mathrm{km}-154^{\circ} \mathrm{C} / \mathrm{km}$ ) at Site 471 , leading to a temperature at maximum depth ranging from $50^{\circ} \mathrm{C}$ to $112^{\circ} \mathrm{C}$ (Site 471 chapter, this volume). No temperature data are available for Site 467 . The value for Site 471 can be compared with the level of organic maturation attained at Site 397 , where a reflectance of $0.45 \%$ was determined at a temperature of only $50^{\circ} \mathrm{C}$, calculated on the basis of various physical parameters by a one-dimensional computer model for a depth of 1300 meters (Cornford et al., 1979; Yukler et al., 1979).

Comparison of Site 471 with Site 467 shows that the stage of maturity is somewhat higher at any given depth level at Site 471 (Figs. 8 and 13). Because the sediment is older at a given depth level at Site 471 than at Site 467, however, the maturation differences may be interpreted as evidence for the importance of time in addition to temperature in controlling the maturation of organic matter in sediments. This implies that the thermal gradient at Site 467 is in the same order of magnitude as at Site 471.

\section{Hydrocarbon Potential}

The organic carbon contents and the predominantly marine type of organic matter in the samples from Site 467 qualify these sediments as good to excellent potential petroleum source rocks. The maturity of the most deeply buried samples and the development of the extract yields downhole indicate that the sediments near bottom-hole depth may be just approaching the onset of major hydrocarbon generation. Minor intercalations of sand layers at different levels may provide possible migration pathways for generated hydrocarbons.

At Site 471 , the kerogen type as well as the total organic carbon content are less favorable for thermal generation of liquid hydrocarbons, but there should be a good potential for gas generation. Hydrocarbon generation may already have started in the lowermost sample investigated. Frequent sand layers provide excellent migration and reservoir facilities.

\section{CONCLUSIONS}

The sediment samples from Site 467 and 471 of DSDP Leg 63 offer an excellent opportunity to study the various effects of the diagenetic development of organic matter from the very immature stages to the onset of thermal hydrocarbon generation. The downhole trends in the extractable as well as the insoluble organic matter can be interpreted in terms of maturation, being controlled by the increase of temperature with depth of burial. Examples are the transformation of sterenes to steranes, the changes in the composition of the aromatic hydrocarbons, increasing extract values below a threshold depth, the degradation of structured liptinites, and the increase of huminite/vitrinite reflectance. More detailed studies are planned on the Leg 63 samples in order to attempt to quantitate and interrelate the processes finally leading to hydrocarbon generation.

\section{ACKNOWLEDGMENTS}

We are indebted to Dr. M. Radke and Dr. R. G. Schaefer for extraction/liquid chromatography and gas chromatography, respectively. We would like to thank $\mathrm{H}$. Willsch for separation of fatty acids and U. Disko for processing mass spectrometric data. We also acknowledge the help of the technical staff of our institutes. And our thanks go to Dr. M. Bjorøy (IKU, Trondheim), Dr. C. Cornford (BNOC, Glasgow), and Dr. M. Hafenrichter (KFA, Jülich) for carefully reading and reviewing the manuscript.

Samples were made available to us through the participation of the Deutsche Forschungsgemeinschaft (DFG) in the DSDP/IPOD program. This is gratefully acknowledged as well as the financial support provided by the German Ministry of Research and Technology (BMFT) Grant No. ET $3070 \mathrm{~B}$ and the Deutsche Forschungsgemeinschaft (DFG) Grant No. We 346/21.

\section{REFERENCES}

Ageta, H., Shioima, K., and Arai, Y., 1968. Fern constituents: neohopane, hopene-II, neohopadiene and fernadiene isolated from Adiantum species. J. Chem. Soc. Chem. Commun., 1105-1107.

Aizenshtat, Z., 1973. Perylene and its geochemical significance. Geochim. Cosmochim. Acta, 37:559-567.

Arthur, M. A., 1979. North Atlantic Cretaceous black shales: the record at Site 398 and a brief comparison with other occurrences. In Ryan, W. B. F., Sibuet, J.-C., et al., Init. Repts. DSDP, 47, Pt. 2 : Washington (U.S. Govt. Printing Office), 719-752.

Blumer, M., and Youngblood, W. W., 1975. Polycyclic aromatic hydrocarbons in soils and Recent sediments. Science, 188:53-55.

Boon, J. J., de Leeuw, J. W., and Schenk, P. A., 1975. Organic geochemistry of Walvis Bay diatomaceous ooze-I. Occurrence and significance of the fatty acids. Geochim. Cosmochim. Acta, 39:1559-1565.

Cornford, C., 1979a. Organic petrography of Lower Cretaceous shales at DSDP Leg 47B, Site 398, Vigo Seamount, eastern North Atlantic. In Ryan, W. B. F., Sibuet, J.-C., et al., Init. Repts. DSDP, 47, Pt. 2: Washington (U.S. Govt. Printing Office), 523-527.

1979b. Petrology of organic matter, DSDP Sites 415 and 416, Moroccan Basin, eastern North Atlantic. In Lancelot, Y., Winterer, E. L., et al., Init. Repts. DSDP, 50: Washington (U.S. Govt. Printing Office), 609-614.

Cornford, C., Rullkötter, J., and Welte, D. H., 1979. Organic geochemistry of DSDP Leg 47A, Site 397, eastern North Atlantic: organic petrography and extractable hydrocarbons. In von Rad, U., Ryan, W. B. F., et al., Init. Repts. DSDP, 47, Pt. 1: Washington (U.S. Govt. Printing Office), 511-522.

, in press. A synthesis of organic petrographic and geochemical results from DSDP sites in the eastern North Atlantic. In Douglas, A. G., and Maxwell, J. R. (Eds.), Advances in Organic Geochemistry-1979: Oxford (Pergamon Press),

Crisp, P. T., Brenner, S., Venkatesan, M. I., et al., 1979. Organic geochemical characterization of sediment-trap particulates from San Nicolas, Santa Barbara, Santa Monica and San Pedro Basins, California. Geochim. Cosmochim. Acta, 43:1791-1801.

Dastillung, M., and Albrecht, P., 1977. $\Delta^{2}$-Sterenes as diagenetic intermediates in sediments. Nature, 269:678-679.

Dierassi, C., Theobald, N., Kokke, W. C. M. C., et al., 1979. Recent progress in the marine sterol field. Pure Appl. Chem., 51:18151828.

Eglinton, G., and Hamilton, R. J., 1963. The distribution of alkanes. In Swain, T. (Ed.), Chemical Plant Taxonomy: London (Academic Press), pp. 187-217.

Ensminger, A., 1977. Evolution de composés polycycliques sédimentaires [Ph.D. thesis]. University of Strasbourg.

Espitalié, J., Laporte, J. L., Madec, M., et al., 1977. Méthode rapide de caractérization des roches-mères, de leur potentiel pétrolier et de leur degré d'évolution. $R$. Inst. Fr. Pét., 32:23-42.

Gagosian, R. B., Lee, C., and Heinzer, F., 1979. Processes controlling the stanol/stenol ratio in Black Sea seawater and sediments. Nature, 280:574-576.

Hitchcock, C., and Nichols, W. B., 1971. Plant Lipid Biochemistry: New York (Academic Press).

Huang, W.-Y., and Meinschein, W. G., 1979. Sterols as ecological indicators. Geochim. Cosmochim. Acta, 43:739-745. 
Jacob, H., 1974. Fluoreszenz-Mikroskopie und Photometrie der organischen Substanz von Sedimenten und Böden. In Freund, H. (Ed.), Handbuch der Mikroskopie in der Technik (4, Pt. 2): Frankfurt/Main (Umschau-Verlag), pp. 369-91.

Kimble, B. J., Maxwell, J. R., Philip, R. P., et al., 1974. Tri- and tetraterpenoid hydrocarbons in the Messel oil shale. Geochim. Cosmochim. Acta, 38:1165-1181.

McIver, R., 1975. Hydrocarbon occurrences from JOIDES Deep Sea Drilling Project. Proc. 9th World Pet. Congr. (Tokyo) (Vol. 2): London (Applied Science Publ. Ltd.), 269-280.

Ourisson, G., Albrecht, P., and Rohmer, M., 1979. The hopanoids. Paleochemistry and biochemistry of a group of natural products. Pure Appl. Chem., 51:709-729.

Radke, M., Sittardt, H. G., and Welte, D. H., 1978. Removal of soluble organic matter from rock samples with a flow-through extraction cell. Anal. Chem., 50:663-665.

Radke, M., Willsch, H., and Welte, D. H., 1980. Preparative hydrocarbon group-type determination by automated medium-pressure liquid chromatography. Anal. Chem., 52:406-411.

Ross, D. A., Neprochnov, Y. P., et al., 1978. Init. Repts. DSDP, 42, Pt. 2: Washington (U.S. Govt. Printing Office).

Roucaché, J., Deroo, G., and Boulet, R., 1979. Caractérization par différentes méthodes physico-chimiques de types de matière organique dans des sédiments du Crétacé d'Atlantique en mer profonde. R. Inst. Fr. Pét., 34:191-220.

Rubinstein, I., Sieskind, O., and Albrecht, P., 1975. Rearranged sterenes in a shale: occurrence and simulated formation. J. Chem. Soc. Perkin Trans. 1, pp. 1833-1836.

Rullkötter, J., Cornford, C., Flekken, P., et al., 1980. Organic geochemistry of sediments cored during Deep Sea Drilling Project Legs 56 and 57, Japan Trench: organic petrography and extract- able hydrocarbons. In Scientific Party, Init. Repts. DSDP, 56, 57, Pt. 2: Washington (U.S. Govt. Printing Office), 1291-1304.

Rullkötter, J., Cornford, C., and Welte, D. H., in press. Petrography and geochemistry of organic matter in Northwest African continental margin sediments: quantity, provenance, depositional environment, and temperature history. In von Rad, U., Hinz, K., Sarntheim, M., et al. (Eds.), Geology of the Northwest African Continental Margin: Heidelberg (Springer Verlag).

Schaeffle, J., Ludwig, B., Albrecht, P., et al., 1978. Aromatic hydrocarbons from geological sources. VI. New aromatic steroid derivatives in sediments and crude oils. Tetrahedron Lett., 4163-4166.

Seifert, W. K., Moldowan, J. M., Smith, C. W., et al., 1978. First proof of structure of a $\mathrm{C}_{28}$-pentacyclic triterpane in petroleum. Nature, 271:436-437.

Stach, E., Mackowsky, M. Th., Teichmüller, M., et al., 1975. Stach's Textbook of Coal Petrology (2nd ed.): Berlin (Gebrüder Borntraeger).

van Dorsselaer, A., Albrecht, P., and Ourisson, G., 1977. Identification of novel $17 \alpha(\mathrm{H})$-hopanes in shales, coals, lignites, sediments and petroleum. Bull. Soc. Chim. Fr., 165-170.

Welte, D. H., Cornford, C., and Rullkötter, J., 1979. Hydrocarbon source rocks in deep sea sediments. Proc. 11th Annual Offshore Techn. Conf. (Houston), 1:457-464.

Wyllie, S. G., and Djerassi, C., 1968. Mass spectrometry in structural and stereochemical problems. CXLVI.-Mass spectrometric fragmentations typical of sterols with unsaturated side chains. J. Org. Chem., 33:305-313.

Yükler, A., Cornford, C., and Welte, D. H., 1979. Simulation of geologic, hydrodynamic and thermodynamic development of a sediment basin-a quantitative approach. In von Rad, U., Ryan, W. B. F., et al., Init. Repts. DSDP, 47, Pt. 1: Washington (U.S. Govt. Printing Office), 761-771. 
APPENDIX

Structural Formulas for Hydrocarbons

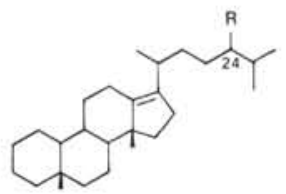

I. rearranged sterenes

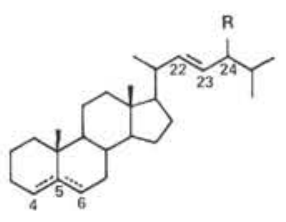

IV. steradienes

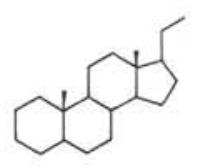

VII. pregnane $\left(\mathrm{C}_{21}\right)$

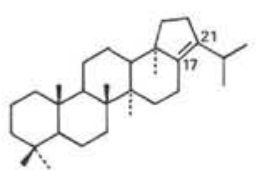

1X. hop.17(21)-ene

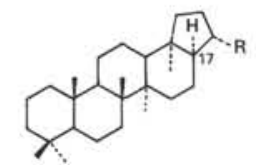

$\mathrm{R}=\mathrm{H}, \mathrm{C}_{2} \mathrm{H}_{5}, \mathrm{CH}\left(\mathrm{CH}_{3}\right)\left(\mathrm{CH}_{2}\right)_{n} \mathrm{CH}_{3}$

XII. 17a(H)-hopanes
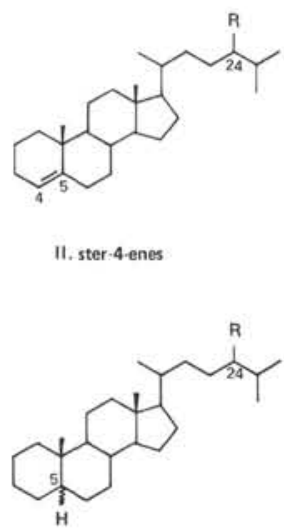

V. steranes

$\mathrm{R}=\mathrm{H}, \mathrm{CH}_{3}, \mathrm{C}_{2} \mathrm{H}_{5}$

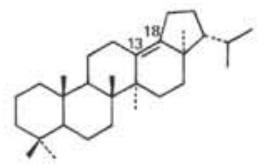

X. hop-13(18)-ene-II

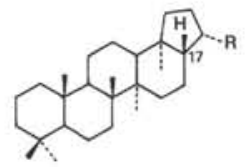

$\mathrm{R}=\mathrm{H}, \mathrm{C}_{2} \mathrm{H}_{5}, \mathrm{CH}\left(\mathrm{CH}_{3}\right)\left(\mathrm{CH}_{2}\right)_{n} \mathrm{CH}_{3}$

XIII. $17 \beta(H)$-hopanes

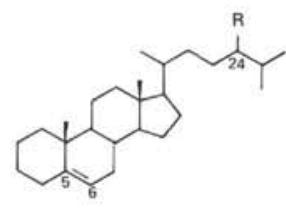

III. ster-5-enes

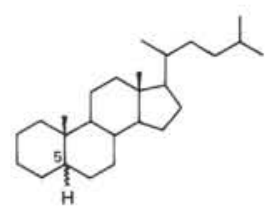

VI. norcholestanes $\left(\mathrm{C}_{26}\right)$

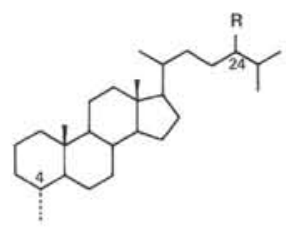

VIII. 4-methylsteranes

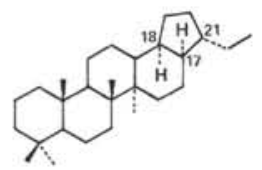

XI. $17 a(H), 18 a(H), 21 \beta(H)$ -

28, 30-bisnorhopane

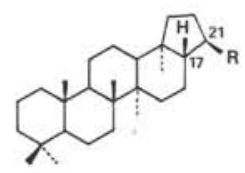

$\mathrm{R}=\mathrm{C}_{2} \mathrm{H}_{5}, \mathrm{CH}\left(\mathrm{CH}_{3}\right)_{2}$

XIV. moretanes
(1)

XV. perylene
$\mathrm{H}_{3} \mathrm{C}+\mathrm{C}_{\mathrm{S}} \mathrm{CH}_{31}$

(1) $\mathrm{C}_{16} \mathrm{H}_{33}$<smiles></smiles>

XVII. $\mathrm{C}_{20} \mathrm{H}_{36} \mathrm{~S}$

XVIII. $\mathrm{C}_{27} \mathrm{H}_{60} \mathrm{~s}$

R: not determined

XIX. monoaromatic steroids<smiles>[R]C(CCC(C)C1CCc2c1ccc1c2ccc2ccccc21)C(C)C</smiles>

XX. triaromatic steroids 